SJ Quinney College of Law, University of Utah

Utah Law Digital Commons

Utah Law Faculty Scholarship

Utah Law Scholarship

2016

\title{
Scrutinizing Immutability: Research on Sexual Orientation and U.S. Legal Advocacy for Sexual Minorities
}

Clifford J. Rosky

S.J. Quinney College of Law, University of Utah, clifford.rosky@law.utah.edu

Lisa M. Diamond

University of Utah

Follow this and additional works at: http://dc.law.utah.edu/scholarship

Part of the Civil Rights and Discrimination Commons, Human Rights Law Commons, and the Law and Gender Commons

\section{Recommended Citation}

Diamond LM and Rosky CJ, Scrutinizing Immutability: Research on Sexual Orientation and U.S. Legal Advocacy for Sexual Minorities, J. Sex Res. 2016 May-Jun;53(4-5):363-91

This Article is brought to you for free and open access by the Utah Law Scholarship at Utah Law Digital Commons. It has been accepted for inclusion in Utah Law Faculty Scholarship by an authorized administrator of Utah Law Digital Commons. For more information, please contact 
THE JOURNAL OF SEX RESEARCH, 53(4-5), 363-391 (2016)

ANNUAL REVIEW OF SEX RESEARCH SPECIAL ISSUE

\title{
Scrutinizing Immutability: Research on Sexual Orientation and U.S. Legal Advocacy for Sexual Minorities
}

\section{Lisa M. Diamond}

\author{
Clifford J. Rosky
}

We review scientific research and legal authorities to argue that the immutability of sexual orientation should no longer be invoked as a foundation for the rights of individuals with same-sex attractions and relationships (i.e., sexual minorities). On the basis of scientific research as well as U.S. legal rulings regarding lesbian, gay, and bisexual (LGB) rights, we make three claims: First, arguments based on the immutability of sexual orientation are unscientific, given what we now know from longitudinal, population-based studies of naturally occurring changes in the same-sex attractions of some individuals over time. Second, arguments based on the immutability of sexual orientation are unnecessary, in light of U.S. legal decisions in which courts have used grounds other than immutability to protect the rights of sexual minorities. Third, arguments about the immutability of sexual orientation are unjust, because they imply that same-sex attractions are inferior to other-sex attractions, and because they privilege sexual minorities who experience their sexuality as fixed over those who experience their sexuality as fluid. We conclude that the legal rights of individuals with same-sex attractions and relationships should not be framed as if they depend on a certain pattern of scientific findings regarding sexual orientation.

In the 2015 landmark decision recognizing a constitutional right to same-sex marriage, Obergefell v. Hodges, the U.S. Supreme Court addressed a question that has long occupied an uncomfortable intersection between science and law: Is sexual orientation an "immutable" characteristic? In striking down state laws against same-sex marriage, the Court declared that, in recent years, "psychiatrists and others [have] recognized that sexual orientation is both a normal expression of human sexuality and immutable" (Obergefell v. Hodges, 2015, p. 8). The Court reasoned that, because sexual orientation is immutable, the petitioners had no real choice but to enter same-sex relationships: "[T] heir immutable nature dictates that same-sex marriage is their only real path to this profound commitment" (p. 4).

In more colloquial terms, the Court has finally picked sides in the age-old nature/nurture debate over sexual orientation: Are lesbian, gay, and bisexual (LGB) individuals "born that way," or do they have any choice in their sexuality? Although this is a fundamentally scientific question, it has been repeatedly posed in political debates about LGB rights. As a result, scientific research has been repeatedly invoked by both advocates and opponents of laws protecting individuals with same-sex sexual orientations (reviewed in Halley, 1994; Hammack \& Windell, 2011; Mucciaroni \& Killian, 2004; Stein, 2014). Specifically, advocates for the rights of lesbians, gay men, and bisexuals have used scientific research on the immutability of sexual orientation to argue that anti-LGB laws violate the U.S. Constitution's Equal Protection Clause, given that the immutability of sexual orientation is one factor that courts have historically considered to determine the constitutionality of such laws.

Our goal is to provide a comprehensive review of the current scientific and legal status of the claim that sexual orientation is immutable, with the goal of demonstrating that immutability should no longer be invoked as a foundation for the rights of individuals with same-sex attractions and relationships (a group we refer to collectively as sexual minorities). We make three specific c claims regarding immutability arguments for the rights of sexual minorities, with special attention devoted to the issue of same-sex marriage in U.S. law. First, arguments based on the immutability of sexual orientation are unscientific c, given that scientific research does not indicate that sexual 


\section{THE JOURNAL OF SEX RESEARCH, 53(4-5), 363-391 (2016)}

orientation is uniformly biologically determined at birth or that patterns of same-sex and other-sex attractions remain fixed over the life course. Second, arguments based on the immutability of sexual orientation are unnecessary, in light of two decades of U.S. legal decisions-including the most recent Supreme Court rulings on same-sex marriage - in which courts have used grounds other than immutability to protect the rights of sexual minorities. Third, arguments about the immutability of sexual orientation are unjust, because they imply that same-sex attractions are inferior to other-sex attractions, and because they privilege sexual minorities who experience their sexuality as fixed over those who experience their sexuality as fluid.

Bisexuality is particularly critical to consider in this regard. Individuals with bisexual attractions and/or behaviors have been largely missing from both scientific and legal debates about the immutability of sexual orientation (Boucai, 2012; Rust, 2000c; Yoshino, 2000), no doubt because their very existence, and the sheer diversity of bisexual pathways and experiences, troubles the rigid categorical distinction between homosexuality and heterosexuality on which immutability debates have been premised (Firestein, 1996; Rust, 2000b, 2000c, 2009; Yoshino, 2000). Of course, the rigidly bounded categories of "homosexual" and "heterosexual" are themselves products of culture, history, and cognition (D’ Emilio, 1983; Foucault, 1980; Herdt, 1990), and many other cultures have more fluid conceptions of gender and sexuality that more easily accommodate bisexuality or that organize sexual identities and relations around dimensions of age, power, gender, and social class rather than (or in addition to) exclusive patterns of same-sex or other-sex desire (Blackwood, 2000; Cardoso \& Werner, 2013; Herdt \& Boxer, 1995; Murray, 2000). Analysis of such cultural differences is beyond the scope of our discussion, but we want to highlight that the theoretical and legal challenges posed by bisexuality flow directly from the West's longstanding overemphasis on homosexual and heterosexual categories of personhood (Sedgwick, 1990). As we address in the third section of this article, such categories fail to represent the true diversity of sexual-minority experience.

Importantly, our focus on same-sex sexuality necessarily neglects other forms of sexual diversity. Scientists and advocates have debated the causes, implications, and legal status of a diverse range of sexual-minority experiences and identities over the past several decades, including polyamory (e.g., openly maintaining more than one intimate relationship at a time), asexuality (e.g., experiencing no sexual attractions), transgender identity and gender variance, and nonnormative erotic practices such as sadomasochism (for relevant reviews, see Emens, 2014; Halberstam, 2005; Kleinplatz \& Diamond, 2013; Minter, 2012; Seto, Abramowitz, \& Barbaree, 2008; Tweedy, 2011). Immutability arguments have relevance for all such forms of sexual and gender diversity, but we constrain our focus to sexual orientation because the legal debates over same-sex marriage have provided the most well-developed "laboratory" for investigating the stakes of immutability claims for sexual-minority rights. As other marginalized groups increasingly advocate for social and legal recognition, we expect that the present analysis will clarify the shortcomings of using immutability claims to protect gender and sexual expression in other settings.

\section{Background on Immutability Arguments in Science and Law}

For more than 50 years, opponents of the rights of sexual minorities have argued that samesex relationships represent deviant lifestyle choices that should be socially discouraged, and advocates for sexual minorities have countered by arguing that sexual orientation is a fixed, biologically based trait that cannot be chosen or changed (Burr, 1996; Caramagno, 2002; Halley, 1994; LeVay, 2011; Mucciaroni\&Killian, 2004; Stein, 2014). These arguments have borrowed their logic from civil rights claims regarding race and ethnicity, essentially claiming that individuals must not be persecuted "on the basis of something about themselves that is fundamentally determined" 


\section{THE JOURNAL OF SEX RESEARCH, 53(4-5), 363-391 (2016)}

(Vargas \& O’ Donnell, 2013, p. 4). The "born/chosen" debate was specifically invoked in amicus curiae briefs filed to the Supreme Court United States v. Windsor and Perry v. Hollingsworth, the 2013 cases on same-sex marriage. For example, Paul McHugh, a psychiatrist at Johns Hopkins, argued in his amicus curiae brief that an equal protection claim could not be made on behalf of sexual minorities because the scientific evidence failed to show that they were a discrete group sharing an immutable trait (McHugh, 2013). The Gay and Lesbian Medical Association submitted their own amicus curiae brief, titled 'On the Immutability of Sexual Orientation" (Vargas \& O' Donnell, 2013), which challenged McHugh's argument and cited a different set of scientific findings to show that sexual orientation was biologically based rather than chosen.

The final decisions in the Windsor and Perry cases did not, in the end, take up the immutability question. And although the Obergefell v. Hodges decision made reference to the immutability of sexual orientation, the concept of immutability played a gratuitous role in the legal reasoning underlying this landmark ruling. Hence, we think it is high time to retire immutability approaches to sexual-minority rights. We are certainly not the first to make this argument (Bruni, 2012; deBoer, 2015; Halley, 1994; Mucciaroni \& Killian, 2004; Warren, 2009). Halley, in particular, published a powerful critique of the immutability approach to sexual-minority rights more than 20 years ago, which remains as pertinent as ever (Halley, 1994). Nonetheless, immutability claims continue to permeate social discourse

about the rights of sexual minorities (e.g., Copland, 2015; Ghose, 2015; Khan, 2015; Rahman, 2015). The climate may finally be ripe for lasting change. We hope that our review of scientific findings and legal rulings regarding immutability will deal these arguments a final and fatal blow.

We begin with a detailed review of scientific evidence on sexual orientation showing that immutability claims have been oversimplified and overgeneralized. We then review recent U.S. court decisions on same-sex marriage, demonstrating the numerous successful legal arguments for the civil rights of sexual minorities which do not depend on the claim that sexual orientation is immutableat least not in the traditional sense meaning that it cannot be chosen or changed. Finally, we conclude by arguing that scientists and legal scholars, within their respective domains, must not privilege the needs and experiences of sexual minorities who experience their attractions as immutable over those who do not.

Because our argument concerns the intersection between science and the law, we include considerable detail on both scientific findings and legal rulings. This format may seem jarring to readers who are more accustomed to purely scientific reviews (which are typically unconcerned with the legal implications of their findings) and purely legal reviews (which are typically unconcerned with the precise details of the scientific findings they cite). Yet we believe an analysis that jointly tackles the scientific and legal basis of immutability arguments is critical to the future contribution of science to the public interest.

\section{IMMUTABILITY CLAIMS ARE UNSCIENTIFIC}

One fact about sexual orientation garners near-universal agreement from scientists: It has no single cause (reviewed in Bailey et al., in press). Rather, multiple biological and nonbiological factors interact to shape the adult expression of same-sex sexuality, and the mix of causal factors may differ from person to person, and for males versus females. We focus here on genetic and neuroendocrine contributions to same-sex sexuality because these contributions have the strongest empirical support. Our summary is necessarily abbreviated, and we refer readers to more comprehensive reviews for greater detail (Bailey et al., in press; Bao \& Swaab, 2011; Hill, Dawood, \& Puts, 2013; Rahman, 2005). 


\section{THE JOURNAL OF SEX RESEARCH, 53(4-5), 363-391 (2016)}

Before turning to the evidence, it is important to note that sexual orientation is not easy to define or measure. This obviously poses a problem for research on the causes of sexual orientation, given that the first step in such research is to identify individuals with different sexual orientations. Sexual orientation is a multifaceted phenomenon, incorporating sexual attractions, sexual arousal, sexual fantasy, sexual behavior, and sexual identity (reviewed in Bailey et al., in press; Klein, Sepekoff, \& Wolf, 1985; Rosario \& Schrimshaw, 2014). Different researchers have emphasized different facets, and the facets themselves do not always coincide. For example, many individuals report same-sex attractions or sexual arousal in the absence of a gay/lesbian/ bisexual identity, and many individuals report bisexual patterns of attraction but pursue exclusively same-sex or othersex relationships (Chivers \& Bailey, 2005; Cramer, Chevalier, Gemberling, Stroud, \& Graham, 2015; Igartua, Thombs, Burgos, \& Montoro, 2009; Lhomond, Saurel-Cubizolles, \& Michaels, 2014; Matthews, Blosnich, Farmer, \& Adams, 2014; Starks, Nadler, Sagrestano, \& Sarvela, 2009).

Cultural factors often contribute to discrepancies between individuals' sexual identities, attractions, and behaviors. Mustanski, Birkett, et al. (2014) pooled two national probability samples, yielding a combined sample size of more than 50,000, to examine ethnic differences in the associations between behavior and identity. Youth in each sexual identity group (gay/lesbian, heterosexual, bisexual) were described as concordant if their identity matched their pattern of behavior (e.g., gay/lesbian youth reporting exclusively same-sex behavior; bisexual youth reporting mixed behavior), and discordant if their identity did not match their pattern of behavior. Black and Hispanic youths in the gay/lesbian group were more likely to be discordant than Whites, yet Black youths in the bisexual group were less likely to be discordant than Whites. The reasons for these differences are not clear, but variation across ethnic groups in the meanings attached to same-sex sexuality likely plays a role. Adolescents who are trying to decide whether they are gay, bisexual, confused, or experimenting will necessarily look to the knowledge, experiences, values, and norms of their local communities, and different ethnic communities will provide sharply different answers. Some communities may discount the relevance of same-sex attractions or behavior, and others may provide no route for youth to develop lesbian, gay, or bisexual identities while maintaining their ethnic identities (Chan, 1995; Consolacion, Russell, \& Sue, 2004; Jamil, Harper, \& Fernandez, 2009; McLean, 2003; Parks, Hughes, \& Matthews, 2004).

Given the degree to which identity and behavior are structured by social context, social constraints, and social opportunities, most researchers treat sexual attractions as the primary indicator of an individual's underlying sexual orientation (Mustanski, Van Wagenen, Birkett, Eyster, \& Corliss, 2014). Yet even attractions do not provide a perfect index, given that they can be influenced by a range of factors other than sexual orientation, such as opportunities to encounter desirable same-sex and other-sex individuals (Diamond, 2003). Although our review will employ the standard scientific (and lay) practice of using the term sexual orientation to denote a consistent pattern of same-sex and/or other-sex sexual attraction, we want to emphasize that none of the studies reviewed here can claim to have definatively assessed the core construct of sexual orientation, given its inherently multidimensional nature. (We will revisit this issue in more detail when discussing the question of whether some individuals can "choose" their orientation.)

\section{Genetic Contributions to Sexual Orientation}

Before we review the extant data on genetic contributions to sexual orientation, a caution is in order: The field of behavioral genetics is currently undergoing a paradigm shift that challenges conventional understandings of genetic inheritance (reviewed in Charney, 2012; Richardson \& Stevens, 2015) due to emerging understandings of phenomena such as epigenetic regulation. Epigenetics focuses on chemical mechanisms that alter the expression of genes at different points in 


\section{THE JOURNAL OF SEX RESEARCH, 53(4-5), 363-391 (2016)}

the organism's life cycle, essentially switching certain genes on and off in response to certain environmental influences. These environmentally released changes can have significant and lasting consequences for the phenotypic expression of genetically influenced traits, and can even be passed down to future generations, directly challenging traditional models of genetic inheritance. Whereas previous behavioral genetic research viewed the DNA sequence as a fixed genetic record constituting the sole mechanism for the inheritance of traits, newer research focuses on the epigenome: the complex constellation of chemical compounds which are not part of the DNA sequence itself but which attach to it and alter gene expression at different stages of the life cycle in response to environmental influences.

Epigenetics opens up exciting new possibilities for investigating the genetic bases of complex traits such as sexual orientation (see Ngun \& Vilain, 2014; Rice, Friberg, \& Gavrilets, 2012). In fact, recent studies using epigenetic models have proven more successful in explaining population variance in same-sex sexuality than studies using conventional genetic models (Ngun et al., 2015). Therefore, future research on the genetics of sexual orientation may increasingly focus on environmentally released changes in gene expression and how these changes are passed down, rather than the simple presence or absence of certain genes at birth. In essence, the current scientific revolution in our understanding of the human epigenome challenges the very notion of being "born gay," along with the notion of being "born" with any complex trait. Rather, our genetic legacy is dynamic, developmental, and environmentally embedded.

The paradigm-shifting insights emerging from postgenomic research (Richardson \& Stevens, 2015) can make it difficult to interpret the findings of older studies using traditional behavioral genetic methodologies, such as twin concordance studies and genome-wide association scans. Yet these are precisely the methods that have been used to study sexual orientation. Findings from these studies (reviewed in this article) still make critical contributions to our understanding of the genetics of sexual orientation, but we expect that our interpretation of these findings will change in future years as postgenomic approaches are increasingly applied to the complex phenomenon of same-sex sexuality.

With this in mind, what have we learned about sexual orientation from conventional behavioral genetic methods? These methods have focused on the heritability of sexual orientation (i.e., the degree to which same-sex sexuality runs in families) and the existence of specific genetic markers associated with same-sex sexuality. Both of these lines of research have found significant evidence for genetic contributions to same-sex sexuality, but neither suggests that sexual orientation is genetically determined. A recent review of the most reliable scientific studies (Bailey et al., in press) estimated that the heritability of sexual orientation is approximately.32, meaning that $32 \%$ of the population variability in sexual orientation is due to genetic factors. (Note that this says nothing about the degree to which a single individual's sexual orientation is genetically influenced; heritability estimates concern variability between persons in a population, not the balance of genetic and environmental influences within persons.)

To provide a basis of comparison, it is helpful to note that higher estimates of heritability (ranging from.4 to.6) have been found for a range of characteristics that are not widely considered immutable, such as being divorced, smoking, having low back pain, and feeling body dissatisfaction (Ferreira, Beckenkamp, Maher, Hopper, \& Ferreira, 2013; Jocklin, McGue, \& Lykken, 1996; KeskiRahkonen et al., 2005; Lessov-Schlaggar, Kristjansson, Bucholz, Heath, \& Madden, 2012). Bailey and colleagues (in press) concluded from their review that sexual orientation is somewhat - but not mostly-genetic, and that it is unquestioningly influenced by environmental factors, given the relatively low concordance of same-sex orientation in identical twins. Concordance refers to the probability that an individual is gay given that his or her identical twin is gay. Across the most 


\section{THE JOURNAL OF SEX RESEARCH, 53(4-5), 363-391 (2016)}

reliable twin registry studies available, the median concordance estimate for sexual orientation among identical twins is. 25 . In summary, despite the fact that identical twins share $100 \%$ of their genes, gay/gay twin pairs are less common than gay/straight twin pairs. The twin data clearly show a genetic contribution to sexuality (because even a twin concordance as low as. 25 is significantly greater than would be expected by chance, given the low base rate of same-sex sexuality in the population), but not genetic determination (which would produce perfect concordance in identical twins).

Other approaches to investigating genetic influences on sexual orientation have focused on identifying specific genetic variants associated with same-sex sexuality. Several comprehensive reviews of these data are available (Dawood, Bailey, \& Martin, 2009; Hill et al., 2013), and so we focus on one of the largest recent studies, whose findings align with the findings of other similar studies. Researchers analyzed the genomes of more than 23,000 men and women that had been collected by the company 23 andMe, and found no genetic loci that were significantly associated with sexual orientation in either men or women (Drabant et al., 2012). However, the marker that came closest to statistical significance among men was located on pericentromeric chromosome 8 , a region which had been identified as a possible marker for male sexual orientation in a previous genomewide association study (Mustanski et al., 2005). As with the findings of heritability, this supports a genetic contribution to sexual orientation, but not genetic determination.

Across all genetic research there has been consistently stronger evidence for genetic influence on male sexual orientation than on female sexual orientation (Bailey et al., in press; Hyde, 2005; Mustanski, Chivers, \& Bailey, 2002). No specific genetic markers appear to be reliably associated with female same-sex sexuality, and heritability estimates for female sexual orientation have varied more widely across different studies than the heritability estimates for male sexual orientation. This might suggest that different genes contribute to female same-sex sexuality than male same-sex sexuality, and it might also be due to the existence of more variable social controls on female than male same-sex sexuality. Although female sexuality has historically been subject to more social control than male sexuality (Baumeister \& Twenge, 2002), stigmatization of homosexuality is typically greater for men than for women (reviewed in Mondimore, 1996). Variable social controls create variable contexts for the expression of genetic predispositions. The heritability of smoking provides an apt analogy, given that social attitudes about smoking (like social attitudes about samesex sexuality) have changed over time and vary widely across different cultures and communities. As Boardman, Blalock, and Pampel (2010) summarized, "When smoking is widely accepted and common, social incentives and motivations to smoke may overwhelm the influence of genetic characteristics. However, when smoking involves controversy over its dangers and the weighing of costs and benefits by individuals, genetic influences may better predict smoking — social smokers with less physical dependence do more to avoid smoking than those with genetic propensities for physical dependence” (p. 109). Similarly, the greater and more consistent stigmatization of male same-sex sexuality than female same-sex sexuality should allow genetic propensities to play a greater and more consistent role in the expression of male than female same-sex sexuality. If cultural attitudes toward female and male sexuality become more similar in the future, then gender differences in the heritability of sexual orientation may change.

Before leaving the topic of genetics, we want to call attention to the cultural privileging of genetic "origin stories." As Halley (1994) noted, one of the factors that fed the increasing prominence of immutability claims for sexual-minority rights in the 1990s was the "cultural success of genetics as a source of knowledge about who we are as humans" (p. 512), fostered by the success of the Human Genome Project. If anything, this fascination with genetic origin stories has only intensified, spurred by the growth of commercial industries purporting to reveal one's own personalized genetic heritage for a fee. Genetic information has also been increasingly used to 


\section{THE JOURNAL OF SEX RESEARCH, 53(4-5), 363-391 (2016)}

investigate and verify the relatedness of cultural groups (most notably indigenous peoples, as shown by TallBear, 2007, 2008), and such practices starkly posit genetics as the ultimate authority on human origins, families, and "types." Although some hope that genetic science will eventually help dismantle systems of oppression by revealing the shared genetic heritage linking disparate groups, genetic science is embedded within larger social and economic systems that typically seek to entrench rather than challenge social hierarchies (TallBear, 2013). Following this reasoning, it may be naive to expect that the identification of a genetic basis for same-sex sexuality will promote its acceptance and social legitimation. Certainly, some individuals would view such findings as further evidence that homosexuality is a disease to be controlled rather than a form of human diversity (Greenberg \& Bailey, 2001; Sedgwick, 1990).

\section{Neuroendocrine Contributions to Sexual Orientation}

Although genetic studies of sexual orientation typically receive the lion's share of attention by journalists, lawyers, and advocates, an equally active line of research concerns exposure to perinatal hormones, sometimes called the neuroendocrine model. The neuroendocrine model is not in competition with genetic models but simply focuses on a different and more specific underlying mechanism. Specifically, this model proposes that variations in exposure to androgens and estrogens in utero may shape later sexual orientation. Prenatal hormonal exposure in utero has welldocumented organizational effects on the developing fetal brain, creating sex differences in regions including the hypothalamus, the septum, the preoptic area, and the amygdala (Baum, 2006; Gooren, 2006; Hines, 2004; Reinisch \& Sanders, 1992). Accordingly, this model hypothesizes that if a boy or a girl is exposed to sex-atypical levels of androgens or estrogens, this exposure may alter the sex differentiation of his or her brain structure in a manner that fosters sexatypical behavior and/or same-sex attraction. Proponents of this model cite animal studies finding that sex-atypical exposure to androgens or estrogens in utero is associated with sex-atypical behavior and partner choice (i.e., male animals show the sexual behaviors and partner choices typically associated with females, and female animals show the sexual behavior and partner choices associated with males, see AdkinsRegan, 2011; Henley, Nunez, \& Clemens, 2011; Roselli \& Stormshak, 2009; Vasey, 2002).

Obviously, it is difficult to extrapolate from animal studies to humans, and the direct evidence for prenatal hormone influences on adult sexual orientation is limited (for detailed reviews and critiques, see Hill et al., 2013; Hines, 2011; Jordan-Young, 2010, 2012; Rahman, 2005). Perhaps the most relevant evidence comes from studies of girls with congenital adrenal hyperplasia (CAH), a condition in which fetuses are exposed to unusually high levels of androgens in utero as a result of disruptions in the synthesis of cortisol by the adrenal gland. Girls with CAH have received so much fetal androgen exposure by the time that they are born that they typically have partially masculinized genitals, which may be surgically altered at birth. As a result, girls with $\mathrm{CAH}$ allow for the investigation of prenatal androgen effects on female sexual orientation: If prenatal androgen exposure is a primary contributor to female sexual orientation, one would expect all CAH girls to develop stable, robust, and consistent lesbian or bisexual orientations, given that they have received a far stronger "dose" of prenatal androgens than the average, non-CAH lesbian or bisexual would be expected to receive.

Yet this is not the case. Longitudinal research has found that although CAH girls are more likely than age-matched controls to report same-sex attractions, the majority identify as heterosexual and report exclusively other-sex attractions and sexual behavior (Meyer-Bahlburg, Dolezal, Baker, \& New, 2008). Hence, as with the genetic data, the evidence does not support straightforward causation. Other human studies investigating the neuroendocrine hypothesis have investigated sexual orientation differences in anatomical characteristics known to be affected by prenatal 


\section{THE JOURNAL OF SEX RESEARCH, 53(4-5), 363-391 (2016)}

hormone exposure (such as the size of specific brain regions) or on maternal characteristics that affect the hormonal milieu experienced by the developing fetus, most notably the number and genders of prior births (for reviews, see Bailey et al., in press; Hill et al., 2013; Hines, 2011; Rahman, 2005). The overall body of evidence is mixed (as critiqued by Jordan-Young, 2012), again suggesting that prenatal hormones potentially contribute to same-sex sexuality in some individuals but do not determine it.

\section{Can Sexual Orientation Change?}

Even if sexual orientation were wholly determined by genes or by perinatal hormones, it would not mean that it was immutable, given that immutable means "unchangeable." Although the status of a trait as biologically determined is often conflated with its capacity to change over the life course, these are not synonymous constructs. Hence, the fact that genes and/or perinatal hormones may contribute to the development of sexual orientation says nothing about whether sexual orientation undergoes change, or whether it can be consciously chosen by individuals who possess no genetic or neuroendocrine predisposition for it. Issues of change and choice have loomed large in debates over sexual- minority rights, going back to Anita Bryant's anti-gay campaign in the late 1970s (Rosky, 2013a, 2013b). Specifically, those opposed to sexual-minority rights have historically argued that sexual minorities are not, in fact, a normal and natural group of individuals suffering unwarranted discrimination but a group that has made harmful and/or immoral sexual choices. According to this view, sexual minorities are fundamentally responsible for any social difficulties they face as a result of these choices, and society should openly marginalize them to discourage other individuals (especially children, as shown in Rosky, 2013a, 2013b) from making the same deviant choices themselves. This logic has been directly invoked in debates over same-sex marriage (Boucai, 2012): Former Supreme Court nominee Robert Bork, for example, argued against same-sex marriage rights on the basis that social acceptance of same-sex relationships might induce other individuals to choose such relationships (Bork, 2004).

Setting aside for now the legal and political effectiveness of these arguments (which we address later), what is their scientific status? Three different lines of evidence speak to these questions. One line of evidence concerns the propensity of individuals to willfully modify their pattern of sexual attraction through sexual orientation change efforts, or SOCE (often colloquially described as "reparative therapy"). A second line of evidence concerns whether sexual orientation appears to undergo longitudinal change on its own, outside the context of therapeutic efforts. A third line of evidence concerns whether some sexual minorities themselves perceive that they have some choice in their same-sex sexuality.

Data bearing on SOCE are perhaps the most relevant because SOCE combines the capacity for change with the capacity for choice. If efforts to willfully change sexual orientation are effective, then individuals with a same-sex orientation can presumably escape discrimination (or could have achieved marriage in the pre-Obergefell era) simply by choosing to change to a heterosexual orientation. (It bears noting, however, that the majority of individuals seeking to change their sexual orientation report doing so for religious reasons rather than to escape discrimination, e.g., Borowich, 2008; Bradshaw, Dehlin, Crowell, Galliher, \& Bradshaw, 2015; Dehlin, Galliher, Bradshaw, Hyde, \& Crowell, 2015; Jones \& Yarhouse, 2011.) In 2009, the American Psychological Association published a comprehensive review of research evaluating the effectiveness and ethics of these therapies. The findings were stark: SOCE are not only ineffective in changing sexual orientation but are psychologically damaging, often resulting in elevated rates of depression, anxiety, and suicidality (APA Task Force on Appropriate Therapeutic Responses to Sexual Orientation, 2009). Although some individuals report satisfaction with the cognitive strategies they have learned for avoiding 


\section{THE JOURNAL OF SEX RESEARCH, 53(4-5), 363-391 (2016)}

same-sex behavior and enhancing emotional connections to heterosexual spouses, the same-sex attractions themselves remain. (And as noted earlier, it is attraction, rather than behavior, which scientists consider to be the key marker of sexual orientation, as reviewed in Mustanski, Van Wagenen, et al., 2014.) The APA report recommends that therapists work sensitively to assist individuals with reconciling their religious and sexual identity but concludes that therapists cannot ethically offer individuals the promise of changing their sexual orientation, given the lack of evidence that such permanent change can be therapeutically achieved.

What about change that occurs outside the context of SOCE? The best and most reliable data on "naturally occurring" change in sexual orientation come from studies that have longitudinally tracked large, population-based samples of heterosexual and sexual-minority individuals (Dickson, Paul, \& Herbison, 2003; Mock \& Eibach, 2012; Ott, Corliss, Wypij, Rosario, \& Austin, 2011; Savin-Williams, Joyner, \& Rieger, 2012; Savin-Williams \& Ream, 2007). Notably, the data provided by these groundbreaking studies were unavailable in the 1980s and early 1990s, when legal arguments regarding the immutability of sexual orientation gained a boost from the growing neurobiological and genetic research on sexual orientation (reviewed by Halley, 1994). At that time, not a single large-scale prospective study on the stability of same-sex attractions had been conducted. Several such studies have now been completed, and they unequivocally demonstrate that same-sex and other-sex attractions do change over time in some individuals. The degree of change is difficult to reliably estimate, given differences in study measures, but the occurrence of change is indisputable. Sections that follow describe the prevalence and direction of change across the most reliable studies; because the succession of statistics can be difficult to digest, a complete tabular summary of these findings can be found in Table 1.

Savin-Williams et al. (2012) analyzed data from the National Longitudinal Study of Adolescent Health (Add Health), which has been regularly tracking same-sex attractions and sexual identity in a random, representative sample of more than 12,000 adolescents since 1994. We focus here on changes in attractions reported between the third wave of data collection (when respondents were between 18 and 24 years old, with a mean age of 22) and the fourth wave of data collection (when respondents were between 24 and 34 years old, with a mean age of 29). We focus on these waves because the measures used to assess same-sex attraction were more specific than at previous waves and hence less likely to have been misinterpreted, and also because evidence suggests that at younger ages, when respondents were around 16 years old, some of the boys' ${ }^{\sim}$ rvv reports of samesex attractions may have been intentionally capricious (i.e., due to "jokester" youths giving false reports; Savin- Williams \& Joyner, 2014).

At the third and fourth waves of data collection, respondents were asked to describe themselves as 100\% heterosexual, Mostly heterosexual, Bisexual, Mostly homosexual, or 100\% homosexual. Of the $5.7 \%$ of men and $13.7 \%$ of women who chose one of the nonheterosexual descriptors at Wave 3, $43 \%$ of the men and $50 \%$ of the women chose a different sexual orientation category six years later. Of those who changed, two-thirds changed to the category $100 \%$ heterosexual. Rates of change were greatest (and transitions to 100\% heterosexual were most common) among those who initially described themselves as Mostly heterosexual (which was the single largest subgroup of nonheterosexuals, accounting for $58 \%$ of the men and $74 \%$ of the women reporting any same-sex attractions). In men, $59 \%$ of the Mostly heterosexual group changed over the following six years, and $82 \%$ of those transitions were to $100 \%$ heterosexual. In women, $47 \%$ of the Mostly heterosexual group changed over the following six years, and $84 \%$ of those transitions were to $100 \%$ heterosexual. In contrast, only $8 \%$ of the exclusively homosexual men and $26 \%$ of the exclusively homosexual women who initially considered themselves exclusively gay changed categories six years later. Of the exclusive heterosexuals, $3 \%$ of the men and $11 \%$ of the heterosexual women switched to a nonheterosexual category six years later. 
Ott et al. (2011) assessed change in sexual orientation in the Growing Up Today Study (GUTS). This study included more than 13,000 youth who were the children of women who participated in the well-known Nurses Health Study II (NHSII), a prospective cohort study of more than 116,000 registered nurses. Although this study did not involve a random representative sample of youth, the size and breadth of the sample contributes unprecedented information on longitudinal change in sexuality during young adulthood. Participants described themselves as Completely heterosexual, Mostly heterosexual, Bisexual, Mostly homosexual, Completely homosexual, or Unsure. Of the $7.5 \%$ of men and $8.7 \%$ of women who chose a nonheterosexual descriptor at ages 18 to $21,43 \%$ of the men and $46 \%$ of the women chose a different category by age 23 . Among the same-sex attracted youth who changed, $57 \%$ of the men's changes and $62 \%$ of the women's changes involved switching to Completely heterosexual.

Table 1. Prevalence of Change in Sexual Attractions Across Longitudinal Studies

\begin{tabular}{|c|c|c|c|c|}
\hline Study & $\begin{array}{l}\text { I. What percentage } \\
\text { of respondents } \\
\text { reported any same- } \\
\text { sex attractions at } \\
\text { first assessment? }\end{array}$ & $\begin{array}{l}\text { II. Of same-sex-attracted } \\
\text { respondents, what percentage } \\
\text { reported any change in } \\
\text { attractions by second assessment } \\
\text { (including switches between } \\
\text { exclusive same-sex attractions } \\
\text { and bisexual attractions)? }\end{array}$ & $\begin{array}{l}\text { III. Of respondents } \\
\text { tabulated in column II, } \\
\text { what percentage changed } \\
\text { to heterosexuality at } \\
\text { second assessment? }\end{array}$ & $\begin{array}{l}\text { IV. What percentage of } \\
\text { respondents who reported } \\
\text { exclusively heterosexual } \\
\text { attractions at first assessment } \\
\text { ended up reporting same-sex } \\
\text { attractions at second assessment? }\end{array}$ \\
\hline $\begin{array}{l}\text { Add Health (Savin-Williams } \\
\text { et al., 2012), } N \sim 12,000 \text {, } \\
\text { change from age } 18-24 \text { to } \\
\text { age } 24-34\end{array}$ & $\begin{array}{l}5.7 \hat{\jmath} \\
13.7 \text { q }\end{array}$ & $\begin{array}{l}430 \\
50\end{array}$ & $\begin{array}{l}660 \\
660\end{array}$ & $\begin{array}{l}80 \\
110\end{array}$ \\
\hline $\begin{array}{l}\text { GUTS (Ott et al., 2011), } \\
N \sim 14,000, \text { change from } \\
\text { age } 18-21 \text { to age } 23\end{array}$ & $\begin{array}{l}7.50 \\
8.7 \text { ㅇ }\end{array}$ & $\begin{array}{l}430 \\
46\end{array}$ & $\begin{array}{l}570 \\
62 \text { ? }\end{array}$ & $\begin{array}{l}4 \hat{\delta} \\
6 \text { q }\end{array}$ \\
\hline $\begin{array}{l}\text { NSMD (Mock \& Eibach, } \\
\text { 2012), } N \sim 5000, \text { change } \\
\text { over } 10 \text { years (respondents } \\
\text { ranged from } 25-74 \text { years of } \\
\text { age at first assessment) }\end{array}$ & $\begin{array}{ll}1 & 0 \\
1 & 0\end{array}$ & $\begin{array}{l}263 \\
640\end{array}$ & $\begin{array}{l}50 \AA \\
550\end{array}$ & $\begin{array}{ll}10 \\
10\end{array}$ \\
\hline $\begin{array}{l}\text { DMHD (Dickson et al., 2013), } \\
\quad N \sim 1000\end{array}$ & & & & \\
\hline Change from age $21-26$ & $\begin{array}{l}4.4 \hat{\delta} \\
9.3 q\end{array}$ & $\begin{array}{l}450 \\
60 \text { 웅 }\end{array}$ & $\begin{array}{l}67 \hat{\jmath} \\
830\end{array}$ & $\begin{array}{l}2 \delta^{\circ} \\
12 \%\end{array}$ \\
\hline Change from age $26-32$ & $\begin{array}{l}5.6 \text { व } \\
17.2 \text { ㅇ }\end{array}$ & $\begin{array}{l}380 \\
580\end{array}$ & $\begin{array}{l}100 \AA \\
91 \%\end{array}$ & $\begin{array}{ll}1 & 0 \\
8 & 0\end{array}$ \\
\hline Change from age $32-38$ & $\begin{array}{l}5.2 \delta \\
14.7 \text { व }\end{array}$ & $\begin{array}{l}26 \hat{\jmath} \\
550\end{array}$ & $\begin{array}{l}67 \hat{\jmath} \\
830\end{array}$ & $\begin{array}{l}2 \hat{\jmath} \\
40\end{array}$ \\
\hline
\end{tabular}

As found with Add Health (Savin-Williams et al., 2012), change was most common among those with attractions to both sexes (including the bisexual group as well as the Mostly heterosexual and Mostly homosexual groups) and least common among those who described themselves as exclusively homosexual. Of those who initially described themselves as exclusively homosexual, 10\% of the men and $33 \%$ of the women changed categories by age 23 . Of those who considered themselves exclusively heterosexual at 18 to 21 years of age, $4 \%$ of the men and $6 \%$ of the women changed categories by age 23 .

The National Survey of Midlife Development (MIDUS) assessed sexual identity at two different points in time, ten years apart, in a representative sample of approximately 2,600 individuals, ranging in age from 25 to 74 (the mean age was 47 at the first assessment). The fact that this study asked individuals whether they were homosexual, heterosexual, or bisexual, rather than simply asking about their same-sex and othersex attractions, is likely responsible for the fact that so few respondents (less than 1\% among both men and women) described themselves as homosexual or bisexual. Yet among this group $64 \%$ of the women and $26 \%$ of the men identified their sexual 


\section{THE JOURNAL OF SEX RESEARCH, 53(4-5), 363-391 (2016)}

orientation differently 10 years later (Mock \& Eibach, 2012). Half of the men's changes and 55\% of the women's changes involved switching to heterosexuality. Similar to the other longitudinal studies cited, changes were less common among those with exclusively same-sex attractions than those with bisexual attractions: Of those who initially considered themselves homosexual (as opposed to bisexual) at Time $1,10 \%$ of the men and $64 \%$ of the women changed categories by Time 2 . Changes were rare among those who initially described themselves as heterosexual; only $1 \%$ of men and 1\% of the women who considered themselves heterosexual at Time 1 changed categories by Time 2 .

The Dunedin Multidisciplinary Health and Development Study (DMHD) is one of the longest-term longitudinal studies (although it does not involve a random sample). A birth cohort of approximately 1,000 New Zealanders in a single city have been observed from their early 20 s to their late 30s (Dickson et al., 2003; Dickson, Roode, Cameron, \& Paul, 2013). Respondents were asked to describe their current pattern of attraction as Only to the opposite sex, More often to the opposite sex but at least once to the same sex, About equally to both sexes, More often to the same sex but at least once to the opposite sex, Only to the same sex, never to the same sex, or Not attracted to anyone. Given the multiple assessments, these data permit us to examine changes between ages 21 and 26, between ages 26 and 32, and between ages 32 and 38. As shown in Table 1, rates of change do not appear to decline as respondents get older. Rates of change in attractions among same-sexattracted men ranged from $26 \%$ to $45 \%$, and rates of change in same-sex-attracted women ranged from $55 \%$ to $60 \%$. Among the same-sexattracted men reporting change, between $67 \%$ and $100 \%$ of the changes were toward heterosexuality, and this also was true for $83 \%$ to $91 \%$ of the same-sexattracted women undergoing changes. Overall, changes among men who identified as heterosexual were observed in $1 \%$ to $2 \%$ of men and ranged from $4 \%$ to $12 \%$ among heterosexual women.

Given the consistency of these findings, it is not scientifically accurate to describe same-sex sexual orientation as a uniformly immutable trait. Although some sexual-minority individuals report consistent patterns of same-sex attraction over time, other sexual-minority individuals undergo changes: sometimes increases/decreases in same-sex attractions and sometimes increases/decreases in other-sex attractions. The question of why such changes occur and why they appear to occur more commonly in women than men remains an active and unresolved topic of debate (Diamond, 2007, 2012; Kuhle \& Radke, 2013; Ross, Daneback, \& Månsson, 2012; Yost \& McCarthy, 2012). Qualitative interview studies indicate that women's changes in sexual attractions are typically experienced as unexpected and unintentional, and are often linked to the onset of specific same-sex or other-sex relationships (Diamond, 2007, 2008b; Golden, 1987). Neurobiological research has documented numerous linkages between the neural substrates of sexual desire and the neural substrates of emotional attachment, and one possibility is that the formation of emotional attachments may facilitate unexpected changes in sexual desire (Diamond, 2003; Diamond \& Dickenson, 2012).

The fact that change appears less common among individuals with exclusive attractions than those with bisexual attractions may suggest that exclusive attractions-whether exclusively same-sex or exclusively other-sex-are fundamentally more stable than bisexual patterns of attraction. Alternatively (or in addition), individuals with bisexual patterns of attraction may have more opportunities for the types of experiences (such as transitions between same-sex and other-sex relationships) that provide catalysts for change, along with a context in which such change can be brought into conscious awareness.

Social influence, in the form of increased visibility and acceptance of same-sex sexuality, may also play a role in longitudinal change. Increases in social acceptance may prove particularly influential for bisexually attracted individuals, who may choose to set aside their capacity for samesex relationships unless they are exposed to social contexts that are supportive and accepting of same-sex sexuality. Arguably, the most supportive and accepting social context for same-sex 


\section{THE JOURNAL OF SEX RESEARCH, 53(4-5), 363-391 (2016)}

sexuality would be a household headed by a same-sex couple: if same-sex sexuality can be enhanced by social acceptance, one would expect that children raised by same-sex couples would be more likely to consider and to pursue same-sex relationships themselves. In fact, this is the case. Longterm longitudinal research on lesbian-headed families (Gartrell, Bos, \& Goldberg, 2011) found that lateadolescent girls who were raised from birth by lesbian parents were more likely than age-matched controls to report same-sex attraction and behavior. The most likely explanation (given that not all of the children were genetically related to their mothers) is that girls raised by lesbian mothers experienced a family climate of acceptance regarding same-sex relationships and received less exposure (relative to the average female adolescent) to conventional societal pressures to pursue exclusively heterosexual relationships. As a result, they may have been more willing and able to consider - and to positively evaluate-their own propensity for same-sex sexuality. Of course, this is exactly what anti-gay activists have long warned about: Anita Bryant cautioned back in 1979 that the agenda of the gay rights movement was to propose to children that same-sex relationships represented an acceptable alternative to heterosexuality, increasing the chance that they would engage in same-sex sexuality themselves (Bryant, 1979). This may be precisely what has happened among the teenagers raised by lesbian-headed families, although contrary to Bryant's warnings they have suffered no psychological, academic, or social deficits as a result (Gartrell \& Bos, 2010).

Interestingly, the propensity for increased social acceptance of same-sex sexuality to foster increased populationwide expression of same-sex sexuality appears to have been happening for some time, especially among women (who, as reviewed, show less evidence for genetic heritability in their same-sex sexuality and greater rates of longitudinal change relative to men). Mercer et al. (2013) analyzed data from three independent administrations (in 1990,1999, and 2010) of the British National Survey of Sexual Attitudes and Lifestyles, each of which used a representative probability sample. The 1990 sample contained more than 18,000 respondents, the 1999 sample contained more than 11,000 respondents, and the 2010 sample contained more than 15,000 respondents. The rates of same-sex behavior among men did not significantly change across the three samples (ranging between $6 \%$ and $8 \%$ ). Yet among women there was a fourfold increase in same-sex behavior (the rate was $3.7 \%$ in $1990,9.7 \%$ in 1999 , and $16 \%$ in 2010). Similar historical changes have been observed in other studies that have analyzed historical trends in the results of populationbased assessments of sexual activity. In the Netherlands, reports of same-sex attraction in women have undergone a sixfold increase, from 3\% in 1989 to 18\% in 2009, and women's reports of same-sex behavior have undergone a threefold increase, from $4 \%$ to $12 \%$. In men, same-sex attractions have doubled from 1989 to 2009, increasing from 6\% to 12\%, although behavior remained stable at around 12\% (Kuyper \& Vanwesenbeeck, 2009). Importantly, these patterns might indicate historical changes in respondents' experience of same-sex sexuality, historical changes in respondents' willingness to disclose same-sex sexuality, or both.

In summary, the data on change are relatively clear: Although therapeutic attempts to change sexual orientation are not successful, patterns of self-reported same-sex and other-sex attraction sometimes change on their own, and the overall social climate of visibility and acceptance regarding same-sex sexuality may be one of the factors influencing such change.

\section{Can Sexual Orientation Be Chosen?}

The quality of the scientific evidence regarding choice is substantially weaker, because it is limited to self-report data on individuals' personal views of their own sexuality. These perceptions, although important and informative, are subject to distortion, bias, poor memory, and limited selfknowledge. The most rigorous research on sexual-minority individuals' perceptions of choice was collected by Herek, Norton, Allen, and Sims (2010) using a national probability sample of lesbian, 


\section{THE JOURNAL OF SEX RESEARCH, 53(4-5), 363-391 (2016)}

gay, and bisexual-identified U.S. adults. Similar to the results of earlier studies using nonrepresentative samples (Diamond, 2008b; Golden, 1994; Whisman, 1996), perceptions of choice varied markedly across gender and orientation subgroups. In all, $10 \%$ of gay men, $30 \%$ of lesbians, and approximately $60 \%$ of bisexual men and women reported having some degree of choice in their sexual orientation.

Of course these data cannot tell us whether individuals are "correct" about having some choice in their sexuality, given that different individuals have different operationalizations of choice (Golden, 1994; Whisman, 1996). For example, some individuals have reported that they consciously decided to think about whether they were capable of a same-sex relationship, and that this choice fostered the subsequent emergence and flourishing of same-sex attractions (Golden, 1996). Other individuals have reported that they chose to stop ignoring or discounting their interest in the same sex, and that once they consciously attended to their feelings they realized that they were sexual attractions (Diamond, 2008b). It is difficult to interpret such reports: Can intentional shifts in attention actually give rise to novel experiences of same-sex (or other-sex) desire, or do these attentional shifts simply foster novel awareness of such desires? This question presumes that individuals can "have" same-sex desires without being aware of them, which does not fit the conventional definition of sexual desire as a subjective experience of sexual motivation.

Perhaps a better way to approach the question of choice is to distinguish between one's conscious experience of same-sex desire and one's capacity for same-sex desire. The latter may be a better operationalization of sexual orientation than the former, but the former is typically the only way to assess the latter. To get around this obstacle, researchers have used a diverse range of objective measures, which are outside of respondents' conscious awareness and therefore difficult to willfully manipulate, to assess men's and women's responses to same-sex and other-sex stimuli, including neuroimaging, eye tracking, pupil dilation, and genital photoplethysmography (Hamann, Herman, Nolan, \& Wallen, 2004; Rieger, Bailey, \& Chivers, 2005; Rieger \& Savin-Williams, 2012; Rosenthal, Sylva, Safron, \& Bailey, 2012; Rupp \& Wallen, 2007; Savin-Williams, Rieger, \& Rosenthal, 2013). Genital photoplethysmography, which assesses genital arousal by measuring the magnitude of blood flow to the genitals, is considered by some to be an objective measure of sexual orientation in men but not in women (Bailey, 2009). Its poor utility for assessing female sexual orientation stems from the fact that women tend to show "nonspecific" forms of genital arousal. As shown by Chivers in a groundbreaking series of studies, women show significant genital arousal to both same-sex and other-sex stimuli, regardless of their self-reported sexual orientation (Chivers, Rieger, Latty, \& Bailey, 2004; Chivers, Seto, \& Blanchard, 2007; Chivers \& Timmers, 2012).

Does this mean that all women are "really" bisexual without being consciously aware of it? Not necessarily: Discrepancies between one's genital arousal to a sexual stimulus and one's psychological experience of arousal are common, especially in women, and it is not clear how to interpret these discrepancies (Bailey, 2009; Bailey, Rieger, \& Rosenthal, 2011; Chivers, Seto, Lalumiere, Laan, \& Grimbos, 2010; Rieger et al., 2005; Rosenthal, Sylva, Safron, \& Bailey, 2011; Rosenthal et al., 2012; Suschinsky, Lalumiere, \& Chivers, 2009). Further complicating the picture is the fact that women show more gender-specific genital responses (i.e., greater arousal to their preferred gender) when sexual stimuli consist of static images of exposed genitals rather than extended videos of individuals engaged in sexual activity (Bouchard, Timmers, \& Chivers, 2015). These findings underscore a point made earlier: There is no agreed-upon direct measure of sexual orientation, which makes it impossible to interpret self-reports of "choice" (as well as change) in sexual orientation.

For the present time, the most accurate summary of the science is that some individuals perceive a role for choice in their sexual orientation and that we do not know what this means. Although "choice" is usually presumed to represent the opposite of "biologically based," no 


\section{THE JOURNAL OF SEX RESEARCH, 53(4-5), 363-391 (2016)}

evidence actually suggests that individuals reporting a role for choice in their sexual orientation are less "biologically gay" than those reporting no role for choice. Given that genetic and neuroendocrine contributions to sexual orientation are not deterministic, one possibility is that a conscious choice to consider same-sex sexuality is necessary for some individuals' biological capacities for same-sex sexuality to become manifest. Even more intriguing, perhaps the only individuals who can truly choose to be gay (i.e., who can intentionally amplify their experience of same-sex desire) are those who already possess a biological predisposition for it, even if they were unaware of this predisposition. Clearly, the simplistic notion of "choice" wielded in public debates over sexual orientation does not do justice to the complex, variable, and multidimensional nature of sexual desire as it is manifested in the mind, brain, and body.

\section{The Gap Between Scientific Findings and Public Advocacy}

Given the weight of evidence challenging (or at least complicating) the immutability argument, why does it continue to hold sway in public discourse on sexual-minority rights (as shown by Stein, 2014)? Some advocates clearly believe that immutability claims are necessary to advocate effectively for sexual minorities. For example, Sullivan (1995) argued forthrightly that to achieve equality, sexual minorities had to insist on "the involuntary nature of their condition" (p. 170). Sullivan's use of the word condition is notable, given that this word calls to mind the historical view of homosexuality as a disease, disorder, or biological flaw(reviewed in Money, 1987; Rosario, 2002). Of course, such views are now widely denounced for their suggestion that homosexuals should be "cured" or eliminated in the same way that other undesirable groups have been historically target for extermination (Khan, 2015).

To say the least, nothing is inherently progressive about immutability claims regarding sexual orientation. And yet, as shown by Stein (2014), the perception that immutability claims are fundamentally linked to sexual-minority civil rights is so pervasive that public figures who question immutability arguments are reflexively considered homophobic (e.g., Bradner \& Jaffee, 2015; Copland, 2014; Ford, 2015). Scientists themselves (including the first author) have sometimes contributed to misconceptions about the immutability of sexual orientation by failing to challenge and unpack these misconceptions in the media, often to avoid having their statements misused by antigay activists (see Throckmorten, 2008, 2009).

After all, the stakes of these arguments can be extremely high: In 2013, President Museveni of Uganda asked scientists to provide him with information on whether sexual orientation is an immutable, biologically determined trait so that he could decide whether homosexuals deserved to be punished for their behavior (Throckmorten, 2013). Museveni was considering whether to sign a law that would strengthen the criminal penalties for homosexuality in Uganda, and he did not think it would be fair to punish individuals who were born abnormal (BBC News, 2014). More than 200 Western scientists submitted a carefully worded letter to Museveni, arguing that although there was no single cause of homosexuality, it was influenced by a range of biological factors, and was not a matter of choice ("Letter to the President of Uganda," 2014). Nonetheless, Museveni signed the law in 2014. (Fortunately, the law was later invalidated on technical grounds.) Since that time, the Academy of Science of South Africa has published its own comprehensive report summarizing the biological evidence regarding sexual orientation and arguing against the criminalization of same-sex sexuality (Academy of Science of South Africa, 2015). The authors deployed the same exaggerations of scientific evidence that have long characterized immutability debates, concluding that "all sexual orientations are biologically based, largely innate and mostly unchangeable" (p. 22).

In African nations, these debates have dire implications: Same-sex conduct is illegal in 37 African nations and punishable by death in seven. When immutability claims are the only way to 


\section{THE JOURNAL OF SEX RESEARCH, 53(4-5), 363-391 (2016)}

save lives, it makes both strategic and moral sense for scientists and advocates to highlight scientific findings that support these claims. Yet in the United States, the social and legal context is obviously more favorable to sexual-minority rights, and immutability claims are no longer necessary, nor particularly effective. It is widely believed that individuals will become less prejudiced against sexual minorities if they come to believe that sexual minorities are "born that way," but there is little evidence to this effect. Although individuals who perceive sexual orientation as biologically based tend to have more positive attitudes toward sexual minorities than those who view sexual orientation as chosen or socially influenced (Halsam \& Levy, 2006; Hegarty \& Pratto, 2001; Landén \& Innala, 2002; Oldham\&Kasser, 1999), it is not clear that born/chosen beliefs actually lead to acceptance/rejection. The elegant studies of Hegarty and colleagues suggest that individuals do not become prejudiced against sexual minorities because they view homosexuality as chosen; rather, they come to endorse notions of homosexuality as chosen as a means of justifying their preexisting prejudice (Falomir- Pichastor \& Hegarty, 2014; Hegarty \& Golden, 2008; Hubbard \& Hegarty, 2014). This is consistent with research showing that the individuals who are most likely to endorse notions of homosexuality as chosen are those who have already rejected homosexuality on moral or religious grounds (Lewis, 2009).

Trying to increase such individuals' acceptance of homosexuality by convincing them that it is immutable is unlikely to be effective (as was the case for President Museveni). Moral and religious beliefs about homosexuality consistently trump "born/chosen" beliefs when predicting attitudes about sexual-minority civil rights (Reyna, Wetherell, Yantis, \& Brandt, 2014), and these moral and religious beliefs are typically long-standing, deeply held, and unlikely to change on the basis of new evidence for genetic or neuroendocrine contributions to sexual orientation. Consider, for example, religious groups that have historically denounced both same-sex attractions and same-sex behavior, such as the Church of Jesus Christ of Latter-Day Saints (sometimes called the LDS or Mormon Church). Over the past decade, the LDS Church has softened its stance toward same-sex attractions, acknowledging that such attractions are not necessarily chosen, that they may be inborn (at least in this life), and that they are not sinful in and of themselves (Oaks, 1995; Church of Jesus Christ of Latter-Day Saints, 2012). Whether or not this softening reflects increased awareness of the biological contributions to sexual orientation, it has not changed the Church's strict condemnation of same-sex behavior and same-sex relationships, and in fact their punishments for same-sex behavior have actually grown more severe since the legalization of same-sex marriage (Goodstein, 2015). Hence, immutability claims may not be as effective as commonly believed in increasing social acceptance of same-sex sexuality.

This is not to say that these claims have no utility whatsoever. For sexual minorities who do experience their same-sex sexuality as early-developing and unchanging, immutability arguments may resonate with their experiences and provide them with a meaningful foundation for their selfacceptance. Also, within highly rejecting contexts (such as a family threatening to disown a gay child because they view same-sex sexuality as a moral failing), immutability arguments may reduce rejection and stigma by countering the view of same-sex sexuality as "blameworthy." As Halley suggests, immutability arguments respond to anti-gay sentiment with "elegant simplicity and plangent appeal" (Halley, 1994). By attempting to bracket the morality of homosexuality, they seem to ask the least of those who oppose it (Sandel, 1989). Rather than ambitiously insisting that "gay is good" (Feldblum, 2005), immutability arguments claim only that homosexuality is "a normal expression of human sexuality," as the Supreme Court asserts (Obergefell v. Hodges, 2015, p. 8). Yet these examples simply underscore the fact that immutability arguments have more to do with dueling cultural values than they have to do with science. Not only has the relevant science been 


\section{THE JOURNAL OF SEX RESEARCH, 53(4-5), 363-391 (2016)}

misrepresented by both sides, but immutability arguments rely on unspoken legal and moral premises whose validity must be questioned.

Before turning to the role of immutability claims in U.S. legal decisions regarding sexualminority rights, we want to address a question we expect readers may have at this point: If, as we have argued, scientific research on the causes of sexual orientation is not relevant to debates over sexual-minority rights, then what sort of science is relevant to these debates, if any? Debating the overarching role of science (and scientists) in advocacy for sexual-minority civil rights (and civil rights advocacy more generally) is beyond the scope of our discussion, and we refer readers to the excellent treatments of this topic elsewhere (Hammack, Mayers, \& Windell, 2013; Kitzinger, 1997; Kitzinger \& Coyle, 1995; Warner, 1999). For our part, we concur with Hammack and Windell (2011) that one of the most indispensable roles for scientific research is to convey the lived experiences of sexual minorities to lawmakers and judges who may have little firsthand knowledge of these experiences. Science cannot and should not be the final arbiter of sexual-minority rights, but research on the origins, development, and experience of same-sex sexuality can and should contribute to the development and laws and policies that reflect the diverse realities of sexualminority lives.

\section{IMMUTABILITY IS UNNECESSARY}

\section{Frontiero v. Richardson: Immutability's Debut}

In the 1938 case United States v. Carolene Products, the Supreme Court laid out a basic framework for analyzing laws challenged under the Equal Protection Clause. Under this rubric, the Court warned that "prejudice against discrete and insular minorities may be a special condition, which tends seriously to curtail the operation of those political processes ordinarily to be relied upon to protect minorities, and which may call for a correspondingly more searching judicial inquiry" (United States v. Carolene Products Co., 1938, p. 152). Unfortunately, the Court made no attempt to identify which minorities were "discrete and insular," and neither of these terms has been meaningfully defined in subsequent cases (Ackerman, 1985). During the 1940s, the Court determined that laws discriminating based on race and national origin were "suspect" and would be subject to "rigid scrutiny" under the Equal Protection Clause (Korematsu v. United States, 1944).

Under this exacting standard, such laws were deemed unconstitutional except in the rare circumstance that the state could show they served a "compelling" state interest. Until the 1970s, however, the Court had still not explained why some classifications were suspect and whether other classifications would be subjected to the same standard. In the 1973 case Frontiero v. Richardson, the Court signaled that heightened scrutiny would apply to sex classifications as well. Writing for a plurality of four justices, Justice Brennan drew a series of analogies between sex and race to explain why discrimination based on both characteristics should be subject to similar standards of judicial review (Frontiero v. Richardson, 1973). Because Brennan's opinion marked the debut of immutability as a legal concept, it remains influential in today's debates about whether sexual orientation is immutable. Furthermore, because the opinion lays out several reasons for applying heightened scrutiny to sex classifications, it is widely referenced to determine the standard for reviewing discrimination against lesbians, gay men, and bisexuals.

Yet Brennan's analogies were not all concerned with the immutability of race and sex. First, he observed that the nation's history of sex discrimination paralleled the history of race discrimination in significant ways, given that, at different historical moments, slaves and women have both been prohibited from voting, holding office, serving on juries, and so on. Second, Brennan insisted that women were still being subjected to discrimination in the workplace, in 


\section{THE JOURNAL OF SEX RESEARCH, 53(4-5), 363-391 (2016)}

educational institutions, and in the political arena partly because of the visibility of the trait of sex. Only after making these points did Brennan argue that sex, like race, was "an immutable characteristic determined solely by accident of birth" (Frontiero v. Richardson, 1973, p. 686). Because these traits bore no relationship to "individual responsibility," he reasoned, imposing "legal burdens" based on them was fundamentally unfair (p. 686). Yet he also claimed that sex was distinguishable from other immutable traits, such as intelligence and physical disability, because sex was rarely relevant to a person's ability to perform a job or contribute to society. Based on the collective strength of these analogies, Brennan concluded that classifications based upon sex-like those based upon race, alienage, and national origin-were inherently suspect. It is this logic that advocates for sexual-minority rights have used in recent debates over same-sex marriage: If sexual orientation represents yet another suspect class, then laws imposing legal burdens on LGB individuals should be subjected to heightened judicial scrutiny to ensure equal protection of the laws.

In future years, judges, lawyers, and scholars began to develop the legal basis for considering sexual orientation as a suspect class. Twelve years after Frontiero was decided, the opinion's author argued that heightened scrutiny should be applied to laws that discriminate against lesbians, gay men, and bisexuals. In Rowland v. Mad River Local School District (1985), a high school guidance counselor named Marjorie Rowland had been suspended solely on the basis of her self-professed bisexuality. When the Supreme Court refused to hear Rowland's appeal, Justice Brennan objected, specifically indicating that discrimination on the basis of sexual orientation raised similar equal protection problems that had been addressed in Frontiero. Yet he did not base this analogy on the immutability of sexual orientation.

Rather, he emphasized the political disenfranchisement of LGB individuals and their exposure to forms of hostility and prejudice that had no rational basis (both of which are factors that courts can consider when evaluating claims of equal protection). For these reasons-and with no reference to immutability - he concluded that state actions taken against LGB individuals should be subjected to heightened scrutiny.

\section{The Mutability of Conduct}

Brennan's sweeping proposal to apply heightened scrutiny to laws affecting sexual orientation was not to be. Just one year after Rowland, the Court decided Bowers v. Hardwick, which dealt a terrible blow to constitutional claims on behalf of LGB litigants (Bowers v. Hardwick, 1986). In this infamous case, the Court upheld the conviction of Michael Hardwick under Georgia's sodomy law for engaging in a private, consensual act of oral sex with another man. Because the law applied to both heterosexual and homosexual conduct, Hardwick challenged his conviction under the Due Process Clause, rather than the Equal Protection Clause-as a violation of his fundamental rights as an individual, rather than as discrimination against LGB people as a class. Based on a misreading of the historical record, the Court rejected Hardwick's claim out of hand, claiming that laws forbidding sodomy had "ancient" roots and that there could be no legitimate assertion of an individual's right to engage in such conduct. Because the law was not subject to heightened scrutiny, it could be justified by any "rational basis"- - including the beliefs of the Georgia electorate that sodomy was an immoral, unacceptable practice.

Strictly speaking, Bowers was about sexual behavior, not sexual orientation. Because the case was decided under the Due Process Clause it did not legally foreclose the possibility of heightened scrutiny for sexual orientation under the Equal Protection Clause. As a practical matter, however, the door that had once been opened by Frontiero had been slammed shut in Bowers. In 1987 one court explained that the two issues could not be distinguished, because sexual orientation was essentially defined by sexual behavior (Padula v. Webster, 1987). The logic went as follows: Because 


\section{THE JOURNAL OF SEX RESEARCH, 53(4-5), 363-391 (2016)}

one's status as an LGB individual is based on one's participation in same-sex behavior, and because the Supreme Court allows states to criminalize same-sex behavior, then the Court clearly does not view sexual orientation as a suspect class. If they did, how could they have permitted criminalization of "the very conduct that defines the class"? Following this logic, several courts rejected the claim that laws regarding sexual orientation merited the same scrutiny as laws regarding race and sex, for equal protection purposes, and they further rejected arguments for heightened scrutiny based on the immutability of sexual orientation.

In 1989 and 1990, courts dismissed equal protection claims by finding that homosexuality was fundamentally different from race, sex, or alienage because it was essentially behavioral (High Tech Gays v. Defense Industry Security Clearance Office, 1990). These early cases highlight one important limitation of immutability claims on behalf of lesbians, gay men, and bisexuals: The immutability argument presumes that sexual orientation can be defined by reference to identity or attraction, rather than conduct. Yet historically most anti-gay laws have targeted homosexual behavior - for example, sodomy and marriage - rather than a claim of identity or same-sex attraction itself. In the late 1980s and early 1990s this definitional gap allowed courts to dismiss claims about the immutability of sexual orientation on the basis that such claims were legally irrelevant: Even if sexual orientation was immutable, these courts reasoned, the law did not target "orientation" per se, only its behavioral manifestations. In 1995 one appeals court explained: "Those persons who fall within the orbit of legislation concerning sexual orientation are so affected not because of their orientation but rather by their conduct which identifies them as homosexual, bisexual, or heterosexual" (Equality Foundation of Greater Cincinnati v. City of Cincinnati, 1995). So long as Bowers remained on the books, lower courts continued to define sexual orientation in behavioral terms - and to reject equal protection challenges brought by lesbians, gay men, and bisexuals on this basis.

Fortunately, those days are long over. In the past three decades, LGB litigants have racked up an astonishing number of victories in state and federal courts-including four landmark victories in the U.S. Supreme Court. These victories might give observers the impression that legal arguments citing the immutability of sexual orientation have, finally, been successful in securing legal protections for sexual minorities. Yet this is not the case. Rather, it is remarkable to see just how few of these victories have depended on the immutability argument. Taking the issue of same-sex marriage as a case study, we can identify five ways that litigants have commonly prevailed without relying on the claim that homosexuality is immutable. These alternative strategies support our claim that the time has finally come for U.S. advocates, lawyers, and scientists to abandon the immutability argument once and for all.

\section{Winning Without Immutability}

It's Just a Factor. Contrary to the notion that the Equal Protection Clause protects only groups who share an immutable trait (as argued in McHugh, 2013), the Supreme Court has historically treated immutability as a factor to be considered rather than a requirement to be fulfilled (Halley, 1994). Moreover, in some decisions (such as Graham v. Richardson, 1971), the Court has applied "heightened scrutiny" for equal protection purposes without making any reference to immutability at all.

Court decisions regarding other stigmatized groups make clear that the immutability of group membership is not a necessary characteristic for a group to fall under the purview of the Equal Protection Clause. In 1971 the Court unanimously determined that alienage classifications were subject to strict scrutiny, just like race and national origin classifications (Graham v. Richardson, 1971). Alienage is obviously not an immutable trait, given that many noncitizens have 


\section{THE JOURNAL OF SEX RESEARCH, 53(4-5), 363-391 (2016)}

the opportunity to become naturalized citizens (Gerstmann, 1999). Similarly, the Court has also applied heightened scrutiny to laws discriminating against children born out of wedlock, even though such children could be "legitimatized" under many states' laws (Gerstmann, 1999; Weber v. Aetna Casualty \& Surety Co., 1972). In later cases, the Court has specifically asked whether groups "exhibit obvious, immutable, or distinguishing characteristics that define them" (Bowen v. Gilliard, 1987, p. 602; Lyng v. Castillo, 1988, p. 638). By using the word "or" rather than "and," the Court indicated that immutability was not a sine qua non for applying heightened scrutiny under the Equal Protection Clause.

Finally, the Court has repeatedly found that immutability by itself is not sufficient grounds for heightened scrutiny. In Frontiero, for example, the Justices observed that laws regarding intelligence and physical disability did not merit heightened scrutiny-despite the immutability of these traits - because such traits were often relevant to an individual's "ability to perform or contribute to society" (Frontiero v. Richardson, 1973, p. 688), therefore creating a potentially rational basis for laws regarding these groups. Accordingly, advocates for same-sex marriage in California, Connecticut, and Iowa have successfully argued that the immutability of sexual orientation is not required for a characteristic to be considered a suspect classification for equal protection purposes, and these courts specifically described immutability as a "subsidiary" or "supplemental" factor for suspect class status, rather than a prerequisite (Kerrigan v. Commission of Public Health, 2008; Marriage Cases, 2008; Varnum v. Brien, 2009).

In United States v. Windsor, a federal appeals court forcefully rejected the claim that a finding of immutability was necessary to define a suspect class. Rather than asking whether homosexuality was immutable, the court asked whether "homosexuality is a sufficiently discernible characteristic to define a discrete minority class" (Windsor v. United States, 2012, p. 183). Although the court acknowledged that this consideration is often couched in terms of immutability, it insisted that the test is broader, focusing on "whether the characteristic of the class calls down discrimination when it is manifest" (p. 183). Because "sexual preference is necessarily disclosed when two persons of the same sex apply for a marriage license," the court found that "sexual orientation is a sufficiently distinguishing characteristic to identify the discrete minority class of homosexuals" (p. 184).

Redefining Immutability. Even in court cases where the immutability of sexual orientation has been invoked to support the rights of LGB individuals, the legal definition of immutability has been altered in significant ways. In short, the key question is no longer "Can LGB individuals change their sexual orientation?" but "Should they be impelled to do so?" At this point, the legal answer is clearly no. In a 1989 case (Watkins v. U.S. Army, 1989), Judge Norris of the Ninth Circuit argued that the Supreme Court's notion of immutability, in the context of equal protection claims, could not mean "strict immutability in the sense that members of the class must be physically unable to change or mask the trait defining their class" (p. 1347). After all, he reasoned, "People can have operations to change their sex. Aliens can ordinarily become naturalized citizens. The status of illegitimate children can be changed" (p. 1347). Taking this analysis a step further, he added that individuals can also change their social status (as a member of a stigmatized group) by simply hiding their group membership.

Yet the fact that individuals possess the option to change a stigmatized trait does not mean that they should have to do so to avoid discrimination. Judge Norris went on to argue that some traits are "so central to a person's identity that it would be abhorrent for government to penalize a person for refusing to change them, regardless of how easy that change might be" (p. 1347), and he maintained that this was the most appropriate definition of "immutable" in the Equal Protection context. By way of example, he continued: "Racial discrimination ... would not suddenly 


\section{THE JOURNAL OF SEX RESEARCH, 53(4-5), 363-391 (2016)}

become constitutional if medical science developed an easy, cheap, and painless method of changing one's skin pigment" (p. 1347).

In the past decade, Judge Norris's redefinition of immutability-from a trait that cannot change to a trait that is central to a person's identity- has been widely adopted by state and federal courts in same-sex marriage cases. In California, Connecticut, and Iowa, the state's highest courts expressly invoked Norris's standard to find that sexual orientation was "immutable" and that heightened scrutiny therefore applied to laws that discriminate against same-sex couples (Kerrigan v. Commission of Public Health, 2008; Marriage Cases, 2008; Varnum v. Brien, 2009). More recently, one federal appeals court adopted his rule, along with several federal district courts that have invalidated same-sex marriage bans (De Leon v. Perry, 2014; Latta v. Otter, 2014; Love v. Beshear, 2014; Obergefell v. Wymyslo, 2013; Varnum v. Brien, 2009; Whitewood v. Wolf, 2014; Wolf v. Walker, 2014).

Of course, this new definition of immutability has little to do with Brennan's original formulation of immutable traits as those which are determined "solely by accident of birth" and unrelated to "individual responsibility" (Frontiero v. Richardson, 1973, p. 686). It is not a definition of immutability at all but a reframing of legal argumentation-from "Can you change?" to "Should you have to change?" (Schmeiser, 2009; Yoshino, 1998). Hence, even when immutability is invoked in arguments seeking protection for sexual minority individuals under the Equal Protection Clause, the legal meaning of immutability has moved far afield from the folk notion of "born that way."

Notably, this redefinition of immutability from a trait that is unchangeable to a trait that is central to a person's identity has its own shortcomings. As noted by Halley (1994), and as we will discuss further, it potentially excludes from legal protection those individuals who do not consider their sexual orientation to be a central and fundamental component of their personal identity (a group that is larger, as we will show, than many might expect). It also leaves open the possibility that laws penalizing same-sex behavior could be found constitutional because they are not penalizing an individual's "personhood" as a sexual minority individual but simply the public expression of that personhood (similar to the rules established in many religious groups, which allow members of these groups to openly identify as lesbian, gay, or bisexual as long as they agree never to act on their samesex attractions). Finally, as critiqued by Clarke, the "new immutability" presumes that some traits are more "central" to a person's identity than others without providing any theoretical justification for these determinations, and ends up relying on the same implicit moral judgments about blameworthiness as did the "old" version of immutability (Clarke, 2015). Yet the key issue, for the present argument, is that even when immutability is successfully invoked to secure legal protections for sexual minority individuals, it is a strikingly different form of immutability that no longer even means "unchangeable."

Sex Discrimination. During the oral arguments in Obergefell, Chief Justice Roberts asked a surprising question about state laws against same-sex marriage:

Counsel, I'm not sure it's necessary to get into sexual orientation to resolve the case. I mean, if Sue loves Joe and Tom loves Joe, Sue can marry him and Tom can't. And the difference is based upon their different sex. Why isn't that a straightforward question of sexual discrimination? (Transcript of Oral Argument in Obergefell v. Hodges, 2015, p. 62)

As the Chief Justice suggested, if his argument were adopted, it would sidestep the issue of whether sexual orientation is immutable, or whether sexual orientation classifications satisfy the factors articulated in Frontiero. If laws against same-sex marriage discriminate based on sex, then 


\section{THE JOURNAL OF SEX RESEARCH, 53(4-5), 363-391 (2016)}

they would be subject to heightened scrutiny on that ground. This particular argument was already familiar to scholars studying the battles over same-sex marriage. In every legal challenge brought since the 1970s, plaintiffs have argued that laws against same-sex marriage should be subject to heightened scrutiny because they discriminate based on sex. In the 1973 case Singer v. Hara, for example, two male plaintiffs claimed that if Washington's marriage law were construed to permit a man to marry a woman but not a man, then it would establish a classification based exclusively on sex which should be subject to heightened scrutiny under the Washington Constitution's Equal Rights Amendment. In response, the state argued that the law did not discriminate based on sex because it applied equally to both sexes (i.e., just as men were forbidden to marry men, women were forbidden to marry women). The Singer court upheld the marriage law, reasoning that because the plaintiffs were members of the same sex, "what they propose is not a marriage" (Singer v. Hara, 1974, p. 1192).

Although the sex discrimination argument was rejected in Singer, it was responsible for the first victory for same-sex marriage in an appellate court. In the 1993 case Baehr v. Lewin, a plurality of the Hawai' i Supreme Court issued the first opinion adopting the sex discrimination argument in a same-sex marriage case (Baehr v. Lewin, 1993). Like the plaintiffs in Singer, the Baehr plurality reasoned that by limiting marriage to male-female couples, the state's law had established a classification that discriminated on the basis of the applicants' sex and was therefore subject to heightened scrutiny under the Hawaii Constitution's Equal Rights Amendment.

The underlying logic of the equal protection argument is inherently compelling. By definition, the concept of sexual orientation depends on the concept of sex (one's own sex combined with the sex of individuals to whom one is attracted). Because it is impossible to make distinctions based on sexual orientation without making distinctions based on sex, every act of discrimination based on sexual orientation can be defined as sex discrimination. This logical relationship is especially clear in the case of laws against same-sex marriage; although such laws are intended to discriminate against gay men and lesbians, they achieve this result by classifying couples based on sex.

In recent years, same-sex marriage advocates have bolstered the sex discrimination argument by documenting the historical connection between discrimination against women and discrimination against lesbians, gay men, and bisexuals —especially in the domain of marriage (Case, 2010). Until the late nineteenth century, marriage laws imposed sexbased roles on husbands and wives. Under the doctrine of coverture, married women were denied the ability to enter contracts, own property, or maintain custody of children upon divorce. Once these inequalities were abolished, legal marriage became the union of two equal partners. Under this regime, as one judge explained, the exclusion of same-sex couples from marriage is nothing more than an "artifact of a time when the genders were seen as having distinct roles in society and in marriage" (Perry v. Schwarzenegger, 2010, p. 993).

Over the years, this argument has proved only modestly successful: Although numerous plaintiffs have challenged the constitutionality of laws against same-sex marriage by arguing that such laws represent sex discrimination, only a handful of trial and appellate judges have accepted this argument. In 2013, however, Justice Kennedy breathed new life into the sex discrimination argument. During oral arguments over the constitutionality of California's Proposition 8, he remarked that the issue of whether Prop 8 "can be treated as a gender-based classification ... [is] a difficult question that I' ve been trying to wrestle with" ("Transcript of Oral Argument in Perry v. Hollingsworth," 2013, p. 13). Given that Kennedy was widely expected to cast the swing vote on same-sex marriage, his remark was carefully noted and deployed by litigants and lower court judges in subsequent cases. In the next marriage case to be decided, a federal judge held that Utah's ban against same-sex marriage was subject to heightened scrutiny because, among other things, the law 


\section{THE JOURNAL OF SEX RESEARCH, 53(4-5), 363-391 (2016)}

was "drawn according to sex" (Kitchen v. Herbert, 2013, p. 1206). As a result, the judge had no need to decide whether sexual orientation was an immutable trait (p. 1207).

Casting Moral Disapproval as Animus. Religious, moral, and social disapproval of homosexuality have long been used as justifications for laws prohibiting same-sex sexual behavior (Bowers v. Hardwick, 1986; Eskridge, 2008). Since 1996, however, the Supreme Court has been rejecting this justification, casting moral disapproval as a form of antigay animus, rather than a legitimate state interest. This approach makes it unnecessary to determine whether sexual orientation is a suspect class (on the basis of its immutability or other criteria), as it removes the rational basis for laws that discriminate on the basis of sexual orientation.

For example, in the 1996 case Romer v. Evans the Supreme Court struck down a law that discriminated against LGB people under the Equal Protection Clause. The law in Romer was an amendment to the Colorado Constitution known as Amendment 2. Titled "No Protected Status Based on Homosexual, Lesbian, or Bisexual Orientation," the law provided that sexual orientation (whether defined in terms of identity or behavior) could not serve as a basis for any claims of discrimination. In effect, the law repealed a number of existing laws that had protected LGB people from discrimination in housing, employment, education, public accommodations, and health and welfare services, and it barred any state or municipal entity from adopting such laws in the future. In defending this law, Colorado principally argued that it would protect the liberty of employers or landlords with personal objections to homosexuality from having to associate with LGB individuals.

In striking down Amendment 2, the Court declined to say whether all classifications based on sexual orientation were suspect, and thus whether they would be subject to heightened scrutiny under the Equal Protection Clause. Because the Court found that Amendment 2 could not even satisfy "rational basis review" - the most deferential standard of judicial review-it was not necessary to determine whether a more demanding standard should be applied. Because the law "identifies persons by a single trait and then denies them protection across the board," it was "at once too narrow and too broad" (p. 633). As a result of this "peculiar property," the Court reasoned, the law was "unprecedented in our jurisprudence" and "inexplicable by anything but animus toward the class it affects" (pp. 632- 633). Quoting an earlier ruling, the Court explained: "[] f the constitutional conception of 'equal protection of the laws' means anything, it must at the very least mean that a bare ... desire to harm a politically unpopular group cannot constitute a legitimate governmental interest" (p. 634).

In the 2003 case Lawrence v. Texas, the Court's rejection of moral objections to homosexuality was more explicit. The law at issue in Lawrence was a Texas statute that criminalized "deviate" sexual intercourse (specifically, anal sex) between persons of the same sex. To justify the law, Texas argued that it was rationally related to "the legitimate governmental interest [in the] promotion of morality" (Respondent's Brief, "Respondent's Brief, Lawrence v. Texas, 2003”, p. 42) — the same interest that the Supreme Court had invoked to justify the sodomy law upheld in Bowers. After criticizing the historical grounds relied upon in Bowers, the Court acknowledged that although many individuals_-over hundreds of years - have expressed powerful and deeply held moral objections to homosexuality, this was not a sufficient justification for criminalizing it, and thereby intruding into citizens' private behavior: “[T] he fact that the governing majority in a State has traditionally viewed a particular practice as immoral is not a sufficient reason for upholding a law prohibiting the practice" (pp. 577-578).

Shortly after Lawrence was decided, the one-two punch of Romer and Lawrence produced a landmark same-sex marriage ruling in Massachusetts. In Goodridge v. Department of Public Health (2003), the Massachusetts Supreme Judicial Court struck down the state's law against same-sex marriage under the state constitution's equal protection and due process provisions. Relying on both 


\section{THE JOURNAL OF SEX RESEARCH, 53(4-5), 363-391 (2016)}

Romer and Lawrence, the Massachusetts court found that the state's law failed rational basis review. As a result, the court did not need to address whether homosexuality was immutable, or whether discrimination based on sexual orientation was subject to a more demanding standard.

Finally, in the 2013 case United States v. Windsor, the Supreme Court struck down the Defense of Marriage Act (DOMA), a federal law that defined marriage as a legal union between one man and one woman. Once again, the Court had an opportunity to say whether laws such as DOMA that discriminated against LGB people were subject to heightened scrutiny under equal protection principles, on the grounds of immutability or other criteria. As noted earlier, several amicus curiae briefs specifically took up this issue, arguing both for (Vargas \& O'Donnell, 2013) and against (McHugh, 2013) the immutability of homosexuality. Yet as in Romer and Lawrence, the Court avoided these issues, invalidating DOMA on more modest grounds. Echoing Romer, the Windsor decision emphasized that discrimination could not be justified by "a bare congressional desire to harm a politically unpopular group" (p. 2693). With unusual candor, the Court declared that DOMA was based on nothing more than "improper animus"—indeed, a desire to "injure" same-sex couples by imposing a stigma on them (p. 2693). In doing so, the Court explicitly rejected Congress's attempts to offer moral justifications for the law, such as the claims that DOMA reflected "a moral conviction that heterosexuality better comports with traditional (especially JudeoChristian) morality" and "an interest in protecting the traditional moral teachings reflected in heterosexualonly marriage laws" (p. 2693). Closely tracking the holding of Lawrence, the Court again found that "no legitimate purpose overcomes the purpose and effect to disparage and to injure those whom the State, by its marriage laws, sought to protect" (p. 2696).

In short, these decisions demonstrate that a more effective (and frankly, more logical) strategy for fighting anti-gay laws is to focus on their "anti" intent. As the Court has ruled, laws that seek to injure, stigmatize, or marginalize a group of people-even on the basis of deeply held moral convictions - are impermissible, regardless of the characteristics of the group targeted by the law.

“You're Harming Our Kids!" In United States v. Windsor, the defenders of "traditional" marriage trotted out a familiar argument in support of DOMA. Among other things, they claimed that the law was justified by the government's interest in promoting child rearing by both a mother and a father. Because of "the different challenges faced by boys and girls as they grow to adulthood," they reasoned, it was "at least rational to think that children benefit from having parental role models of both sexes" (Brief on the Merits for Respondent the Bipartisan Legal Advisory Group of the U.S. House of Representatives, United States v. Windsor, 2013, p. 48).

Yet in striking down DOMA, the Supreme Court ruled that the law actually harmed children, rather than benefiting them. In addition to finding that the law "injure[s]," "disparage[s]," and "demean[s]" same-sex couples, the Court declared that DOMA "humiliates tens of thousands of children now being raised by same-sex couples" (United States v. Windsor, 2013, p. 2694). The Court added that "DOMA also brings financial harm to children of same-sex couples" by raising "the cost of health care for families" and denying "benefits allowed to families upon the loss of a spouse and parent" (p. 2694). This argument, too, does not depend on any claim that homosexuality is immutable — or more broadly, on the application of heightened scrutiny to laws that discriminate against LGB people. It depends only on the recognition that some same-sex couples are raising children. Once this fact is acknowledged, it follows that laws targeting same-sex couples harm these children.

It is difficult to overstate the significance of this particular turn in the trajectory of the LGBT movement. For many decades, courts had presumed that the government had a legitimate interest in shielding children from any exposure to homosexuality-most notably, to prevent children from becoming lesbian, gay, or bisexual themselves. In the name of protecting children 


\section{THE JOURNAL OF SEX RESEARCH, 53(4-5), 363-391 (2016)}

from concerns about seduction, indoctrination, and role modeling, opponents of LGB rights such as Anita Bryant had defended a broad range of policies that discriminated against LGB people. Yet the Court's analysis in Windsor provides a new and powerful response to the claim that anti-gay laws especially those that prohibit same-sex marriage-seek to protect children: Advocates, lawyers, and scientists can now effectively argue that the children who need protection are the children of LGB individuals, who are harmed and humiliated by laws that codify anti-gay animus.

The Liberty to Choose. In Lawrence, the Supreme Court struck down the Texas sodomy law under the Due Process Clause rather than the Equal Protection Clause. In doing so, the Court opened up yet another path around the immutability argument, by establishing each individual's liberty to choose same-sex relations and relationships. Throughout the proceedings, the two men had challenged their sodomy convictions under both the Equal Protection Clause and Due Process Clause - as a form of discrimination against gay and lesbian people as well as an infringement on an individual's liberty to engage in private consensual sexual behavior. Rather than deciding the case under the Equal Protection Clause — and thus leaving the holding of Bowers untouched — the Lawrence Court clearly stated that it was deciding the case under the Due Process Clause. Analogizing the men's claim to the liberty interests protected in the Court's reproductive freedom cases involving abortion and contraceptives, the Court emphasized that the Texas sodomy law sought "to control a personal relationship that ... is within the liberty of persons to choose without being punished as criminals" (Lawrence v. Texas, 2003, p. 567). From this perspective, the immutability of the men's desire to engage in same-sex contact was irrelevant. Accordingly, the Court made no reference to immutability, instead referring repeatedly to the themes of liberty, freedom, and choice: "It suffices for us to acknowledge that adults may choose to enter upon this relationship in the confines of their homes and their own private lives and still retain their dignity as free persons.... The liberty protected by the Constitution allows homosexual persons the right to make this choice" (p. 567; emphasis added).

In subsequent cases, lower courts have applied Lawrence to recognize that laws against same-sex marriage violate an individual's right to marry, which the Supreme Court has long recognized as a fundamental right protected by the Due Process Clause. In 2008, the California Supreme Court applied Lawrence in holding that California's law against same-sex marriage violated "the right of an individual to establish a legally recognized family with the person of one's choice" (Marriage Cases, 2008, p. 423). More recently, in Kitchen v. Herbert, a federal appeals court applied Lawrence in holding that Utah's law against same-sex marriage violated the fundamental right to marry-specifically, the "freedoms - to choose one's spouse, to decide whether to conceive or adopt a child, to publicly proclaim an enduring commitment to remain together through thick and thin" (Kitchen v. Herbert, 2013, p. 1212). These rulings show the viability of arguments for samesex marriage that focus on the fundamental right to choose one's marriage partner, rather than one's inability to change one's same-sex desires.

For the most part, the Supreme Court's recent ruling in Obergefell offered a ringing endorsement of an individual's liberty to choose same-sex relationships. Above all, the Court emphasized that "the right to marry is fundamental under the Due Process Clause" because "the right to personal choice regarding marriage is inherent in the concept of individual autonomy" (Obergefell v. Hodges, 2015). Drawing upon earlier rulings, the Court analogized the freedom to marry with other liberties protected by the Due Process Clause: Like choices concerning contraception, family relationships, procreation, and child rearing, "decisions concerning marriage are among the most intimate that an individual can make" (p. 12; emphasis added). Because the freedom to marry resides "with the individual," the Court explained, "[t]his is true for all persons, 


\section{THE JOURNAL OF SEX RESEARCH, 53(4-5), 363-391 (2016)}

whatever their sexual orientation" (p. 13). Summarizing this analysis, the Court concluded: "There is no difference between same- and opposite-sex couples with respect to this principle" (p. 17).

In light of this reasoning, it was both puzzling and pointless that the Obergefell decision also stated that "sexual orientation is ... immutable" (p. 8) and that the "immutable nature" of the petitioners "dictates that same-sex marriage is their only real path to [the] profound commitment" that marriage involves (p. 4). If every person has the "autonomy to make such profound choices" ( $p$. 13), then why should the reasons underlying those choices matter? One man seeking to marry a same-sex partner may feel that he was born with a gay orientation and had "no choice" but to fall in love with a man. Another man might feel that although he did not choose his bisexual attractions, he actively chose to pursue relationships with men instead of relationships with women. Do laws against same-sex marriage violate the freedom of gay men more than the freedom of bisexuals (see Boucai, 2012)?

Given that the Supreme Court ultimately ruled in favor of same-sex marriage, one might wonder whether the Court's casual, scientifically inaccurate references to immutability really matter, especially given that they were not invoked as the primary basis for the judgment itself. In other words, now that same-sex marriage is legal for everyone, what is the harm if the Supreme Court has a view of sexual orientation that is several decades out of date? We are not worried that after Obergefell county clerks will require same-sex couples to prove that they were "born that way" or deny them marriage licenses if they fail to do so. But the Court's opinion is a social artifact as well as a legal ruling - a widely read text that may influence how LGB people are perceived by others, and how they perceive and present themselves (Halley, 1998). In this sense, the Court's cryptic reference to immutability is not only gratuitous but actually harmful. It implicitly presumes that homosexuality is inferior to heterosexuality, and it symbolically excludes certain subsets of the sexual minority population from the very freedoms and relationships that Obergefell purports to protect. This is the argument we take up next.

\section{IMMUTABILITY IS UNJUST}

The final and crucial reason to set aside immutability-based arguments for sexual-minority rights is that they misrepresent and marginalize those sexual minorities who experience their sexuality as chosen, nonexclusive, or variable, implying that these individuals are somehow less deserving of legal protection than sexual minorities who experience their sexuality as fixed, exclusive, and essential. Also, by making the claim that sexual minorities cannot be held not "responsible" for their status, immutability arguments signal fundamental agreement with the historical denigration of same-sex sexuality as inherently inferior to heterosexuality.

\section{Who Deserves Equal Treatment?}

If the immutability of sexual orientation is used as the basis for civil rights claims on behalf of sexual minorities, then what happens to the legal and social identities of individuals whose samesex sexuality does not appear to be immutable? The two types of sexual minorities who are most marginalized and disenfranchised by immutability arguments are bisexual individuals and those who experience their sexuality as variable and/or chosen.

Individuals with bisexual patterns of attraction and behavior have always posed a problem for immutability claims, especially as these claims have been applied to the same-sex marriage debate (Boucai, 2012). As reviewed by Halley (1994), courts have interpreted arguments about the immutability of sexual orientation to be irrelevant to the "great in between" occupied by bisexuals (p. 515), reflecting the widespread view that individuals who possess attractions to both men and 


\section{THE JOURNAL OF SEX RESEARCH, 53(4-5), 363-391 (2016)}

women necessarily have some degree of choice over which relationships to pursue (a view which some-but not all—bisexuals share, as shown by Herek et al., 2010). As Halley (1994) warned, "[T] he fairness theory of pro-gay essentialism does not explain why bisexuals-by hypothesis capable of satisfactory sexual encounters with members of the so-called 'opposite' sex-should not be encouraged or forced to do so"' (p. 528), and she further warned that this particular problem with the immutability argument would only get worse as bisexual movements and communities began to grow.

Her words seem unusually prescient now: At the time of her writing, in the early 1990s, bisexual identities and communities were relatively novel phenomena, lacking the size, political power, and visibility of the conventional lesbian/ gay community. Twenty years later, social and scientific c awareness of bisexuality, and the development of bisexual communities and advocacy groups, has increased substantially. Although it is commonly thought that bisexuals face less social marginalization than gays and lesbians because they have access to the privileges associated with heterosexual relationships, this does not appear to be the case: To the contrary, bisexuals face widespread suspicion, dismissal, misunderstanding, and denigration from both mainstream society and the lesbian/gay community (Balsam \& Mohr, 2007; Callis, 2013; Kaestle \& Ivory, 2012; WelzerLang \& Tomolillo, 2008; Yost \& Thomas, 2012), and this pervasive stigmatization may account for the fact that bisexually attracted and bisexually behaving individuals report higher levels of stressrelated mental health problems (such as anxiety, depression, and substance use) than individuals with exclusively same-sex attractions or behavior (Diamond, Butterworth, \& Savin-Williams, 2010; Dodge \& Sandfort, 2007; Gorman, Denney, Dowdy, \& Medeiros, 2015).

The fact that bisexually attracted individuals can choose to form relationships with either other-sex or same-sex partners remains a key reason for the animus directed toward them, given that the specter of "choice" has been used as a tool to undermine the rights of sexual minorities. If, as Sullivan (1995) argued, sexual minorities must secure their rights by convincing the public that they bear no responsibility for their "condition," then the very existence of bisexuals threatens that strategy: Even if bisexual attractions are just as immutable as exclusive same-sex attractions, the inherent possibility for choice in the behavior of bisexuals undercuts the immutability approach (Yoshino, 2000). The very moment that a bisexual man makes a decision about whether to pursue a same-sex partner versus an other-sex partner, he conceivably bears some degree of responsibility for any resulting marginalization. Although he may not have chosen to be bisexual, he chose what to do about it, and can therefore be held liable for making the wrong choice. Note that when we refer to "pursuing same-sex partners," we denote conscious decisions to act on same-sex attractions (and romantic attachments) by entering into sexual or romantic relationships, and we do not imply that individuals can consciously control the experience of falling in love, or the degree to which they find one relationship more satisfying and fulfilling than another.

Boucai (2012) has eloquently argued that bisexuals actually have more to lose than lesbians and gay men in the face of laws which incentivize certain relationships over others. Specifically, because bisexuals can choose to pursue either same-sex or other-sex relationships, their lives and relationships are the most effectively coerced and channeled by laws recognizing other-sex marriage but not same-sex marriage. According to this compelling logic, bisexuals present the most clear-cut case of state interference into one of the most personal and private decisions in one's life: not just whether to marry, but whom. Boucai's argument draws on Adrienne Rich's (1980) famous notion of "compulsory heterosexuality." Rich argued that women's "choices" to pursue heterosexual relationships were fundamentally enforced by social norms privileging heterosexuality, positing it as natural, attaching economic resources to it, and punishing women for deviating from it. In essence, when there is such a huge discrepancy between the social and economic costs and benefits of samesex versus other-sex relationships, the choice of an other-sex over a same-sex partner is never a free 


\section{THE JOURNAL OF SEX RESEARCH, 53(4-5), 363-391 (2016)}

choice. Immutability-based strategies for sexual-minority rights are incapable of critiquing and dismantling this DIAMOND AND ROSKY 380 Downloaded by [University of Utah] at 15:57 15 July 2016 form of social control: How can one protect bisexuals' ability to choose same-sex partners if one fails to acknowledge that such choices are possible? Immutability strategies for sexualminority rights do not account for the unique experiences of individuals with bisexual attractions.

This weakness would be important even if there were only a handful of bisexually attracted individuals in the overall sexual minority population, but its implications are magnified by the fact that there are far more bisexuals in the population than most people think, rendering their exclusion from immutability arguments even more egregious.

\section{The Invisible Majority}

Although many scholars of sexuality such as Freud (1920) have suggested that humans are innately bisexual, modern sexuality research has generally considered bisexuals to be a small, "fringe" part of the sexual minority population, presumably made up of individuals who were in the process of transitioning to a gay or lesbian identity or individuals who were temporarily experimenting with same-sex relationships (Diamond, 2008a; Rust, 1993, 2000a). From this perspective, exclusive homosexuality represents the modal form of same-sex sexuality and bisexuality constitutes an exception. Up until the 1990s, there was little reason to doubt this view, given that the majority of research conducted on sexual minority populations recruited participants through openly LGB organizations, events, businesses, and newspapers, all of which tended to underrepresent bisexually identified men and women.

Today scientists realize how these strategies have distorted our perceptions of the bisexual population, now that we have access to large-scale, random, and representative data on the distribution of same-sex sexuality in the United States and other nations. Quite simply, individuals with bisexual attractions are not "exceptions" within the sexual-minority populations, but the most common type of sexual minority. To be sure, many of these individuals do not openly identify as bisexual; some identify as lesbian and gay, some as heterosexual, and some adopt no sexual identity label at all (reflecting, as discussed earlier, the widespread discordance among the domains of attraction, behavior, and identity within the sexual-minority population). But studies assessing patterns of sexual attraction (as opposed to identity or behavior) consistently show that individuals with a capacity for bisexual attractions outnumber individuals with exclusive same-sex attractions (Chandra, Mosher, Copen, \& Sionean, 2011; Gates, 2011; Hayes et al., 2012; Laumann, Gagnon, Michael, \& Michaels, 1994; Mosher, Chandra, \& Jones, 2005; Savin-Williams, 2006). For example, one large-scale representative study of American adults (Mosher et al., 2005) found that 6\% of American men and nearly $13 \%$ of American women reported attractions to both sexes, whereas $1.5 \%$ of men and. $\%$ of women were exclusively attracted to the same sex (the same basic pattern emerged in Chandra et al., 2011). In the fourth wave of the National Longitudinal Study of Adolescent Health (when participants were in early adulthood), $6.4 \%$ of men and nearly $20 \%$ of women reported same-sex attractions, and of these individuals, only $5 \%$ of the same-sex attracted women and $26 \%$ of the same-sex attracted men reported that these attractions were exclusively directed to the same sex.

Similar results have been found internationally: A probability sample of approximately 4,000 British adults found that $5.1 \%$ of men and $6 \%$ women reported a same-sex attractions; of these individuals, only $10 \%$ of the women and $20 \%$ of the men described their attractions as exclusively same-sex (Hayes et al., 2012). In a large cohort study of New Zealanders, 5.6\% of men and 15.9\% of women reported same-sex attraction; of these individuals, $5 \%$ of the women and $21 \%$ of the men described their attractions as exclusively same-sex (Dickson et al., 2003). In a representative 


\section{THE JOURNAL OF SEX RESEARCH, 53(4-5), 363-391 (2016)}

probability sample of nearly 6,000 American adults, $7.8 \%$ of men and $6.8 \%$ claimed to be nonheterosexual; of these individuals, two-thirds of the men but only $14 \%$ of the women claimed to be exclusively gay/lesbian (Herbenick et al., 2010). In a nationally representative survey of more than 33,000 men and women, $1.5 \%$ of men and 1.4\% of women identified as nonheterosexual; of these individuals, $78 \%$ of the men but only $42 \%$ of the women considered themselves exclusively gay or lesbian (Sweet \& Welles, 2012). In a representative study of nearly 3,500 Swedish youth (17 to 18 years of age), only $3 \%$ of the same-sex-attracted women and $11 \%$ of the same-sexattracted men considered themselves exclusively gay (Priebe \& Svedin, 2013). Among a representative schoolbased sample of nearly 4,000 youth in Canada, only $6 \%$ of the same-sex-attracted girls and $25 \%$ of the same-sexattracted boys described their attractions as exclusively same sex (Busseri, Willoughby, Chalmers, \& Bogaert, 2006). These findings challenge the conventional wisdom that individuals with exclusive same-sex attractions represent the prototypical "type" of sexual minority individual, and that those with bisexual patterns of attraction are infrequent exceptions. In most studies, the opposite appears to be true: among individuals with same-sex attractions, individuals with nonexclusive patterns of attraction are indisputably the "norm," and those with exclusive same-sex attractions are the exception.

Perhaps most interesting of all, a range of studies has revealed that the single largest subgroup of individuals with same-sex attractions, among both women and men, is comprised of individuals who consider themselves "mostly but not completely heterosexual" (Savin-Williams \& Vrangalova, 2013). These individuals have historically received almost no research attention, and they certainly do not fit anyone's stereotype of the type of sexual minority who has been harmed by the historical unavailability of same-sex marriage. Of course, identifying this population is difficult because few large-scale studies bother to ask heterosexually identified respondents whether they ever experience same-sex attraction. Yet the studies that have done so provide a fascinating perspective on "hidden" bisexual attractions and behavior among heterosexually identified adolescents and adults. For example, a random representative sample of more than 12,000 New Zealanders over age 16 found that $3 \%$ of the respondents who considered themselves to be heterosexual reported having had same-sex sexual experiences (Wells, McGee, \& Beautrais, 2011). A representative survey of 7,403 adult men and women in the United Kingdom found that 1\% of those who considered themselves completely heterosexual had engaged in same-sex sexual behavior (Chakraborty, McManus, Brugha, Bebbington, \& King, 2011). A representative school-based sample of nearly 2,000 high school students in Quebec found that 5\% of the youth who considered themselves heterosexual reported experiencing same-sex attractions and $2 \%$ reported same-sex behavior. A representative sample of more than 3,000 Swedish high school students (Priebe \& Svedin, 2013) found that $13 \%$ of the heterosexually identified boys and $30 \%$ of the heterosexually identified girls reported some degree of same-sex attraction ( $1 \%$ of the heterosexual boys and $2 \%$ of the heterosexual girls also reported same-sex sexual behavior). The National Epidemiologic Survey of Alcohol and Related Conditions collected data on sexuality from a representative sample of more than 34,000 adults and found that $2 \%$ of the heterosexually identified respondents reported samesex attractions and 1\% reported same-sex behavior (Sweet \& Welles, 2012). Pooled representative data from multiple administrations of the Youth Risk Behavior Survey, yielding a combined sample of more than 50,000 adolescents, found that $5 \%$ of heterosexually identified youths reported having had same-sex sexual partners prior to age 18 (Mustanski, Birkett, et al., 2014).

In light of such findings, researchers studying sexual orientation have recently begun to devote more systematic attention to bisexual patterns of attraction and behavior, whether they occur among bisexual-identified, heterosexual-identified, or gay/lesbian-identified individuals. However, such studies remain woefully underrepresented in the overall research literature on sexual orientation. For example, a recent search of the peer-reviewed social science literature found that 


\section{THE JOURNAL OF SEX RESEARCH, 53(4-5), 363-391 (2016)}

from the mid-1970s to the mid-1980s only $1 \%$ of journal articles focusing on sexual orientation or sexual minority individuals had the word bisexual in the title, and only $9 \%$ contained the word in the abstract. Between 1994 and 2005, these percentages increased to $14 \%$ and 35\%, respectively, and during the past decade they have increased to $20 \%$ and $55 \%$. Echoing this scientific omission, bisexuals have also received little attention in legal scholarship on sexual minority rights. As argued by Yoshino (2000), bisexuals have faced systematic "erasure" from legal and political discourse about sexual minority rights, and he maintains that this erasure has been maintained for strategic reasons, most notably to stabilize the existing categories of homosexuality and heterosexuality and to maintain cultural norms of monogamy. Hence, bisexuals have been altogether absent from both scientific and legal discourses about the immutability of sexual orientation and its relevance to sexual minority rights.

Individuals who openly claim to have chosen their same-sex sexuality represent another group that is misrepresented and marginalized by the immutability approach for sexual-minority rights. Both scientists and laypeople commonly claim that same-sex sexuality is rarely or never chosen (e.g., American Psychological Association, 2008; Ghose, 2015), and individuals who claim otherwise (or who imply the capacity for choice by using terms such as sexual preference instead of sexual orientation) are often interpreted as misguided, insensitive, or homophobic (Bering, 2013; Burnett, 2015).

Yet similar to bisexuals, individuals who perceive that they have some choice in their samesex sexuality are more numerous than most people think. As noted earlier, a recent survey conducted by Herek and colleagues (2010) found that 10\% of gay men, $30 \%$ of lesbians, and approximately $60 \%$ of bisexuals reported having some degree of choice in their sexuality. These data are often summarized as evidence that the majority of gays and lesbians do not feel that they chose their sexual orientation, but such a summary overlooks the obvious finding that a majority of bisexuals do feel they have some choice. It is not surprising that the reports of the bisexuals are downplayed, given that claims of choice are perceived to be damaging to immutability arguments for sexual minority rights. This perception is so well-entrenched that the LGBT community has openly scolded individuals who describe their own sexuality as chosen. For example, actress Cynthia Nixon, who developed a committed relationship with a woman in her 40s after an exclusively heterosexual history, faced widespread skepticism from the LGBT community for openly claiming to "prefer" same-sex sexuality: "I gave a speech recently, an empowerment speech to a gay audience, and it included the line 'I've been straight and I've been gay, and gay is better.' And they tried to get me to change it, because they said it implies that homosexuality can be a choice. And for me, it is a choice. I understand that for many people it's not, but for me it's a choice, and you don't get to define my gayness for me ... let us stop trying to make a litmus test for who is considered gay and who is not.... Why can't it be a choice? Why is that any less legitimate?" (qtd. in Witchel, 2012).

There is a long history to the notion of a "litmus test" for sexual orientation, in which some sexual minorities are considered to be more "authentically" gay (and hence more deserving of legal protections) than others. From a scientific perspective, researchers have historically contrasted "constitutional" same-sex sexuality, theoretically attributable to an intrinsic predisposition for the same sex, with "facultative" or "opportunistic" same-sex sexuality, theoretically attributable to reduced opportunities for othersex contact, prolonged sex segregation, curiosity, confusion, or experimentation (Bell, Weinberg, \& Hammersmith, 1981; Money, 1988; Muscarella, 1999). Constitutional same-sex attractions are presumed to be exclusive, early developing, and longitudinally stable, whereas facultative same-sex attractions are presumed to be unstable and situationally variable. Laypeople, too, commonly make these distinctions. For example, women who pursue same-sex activity in the relatively tolerant environment of college but resume exclusive heterosexual behavior afterward are jokingly called "LUGs," or "lesbians until graduation" (Davis, 


\section{THE JOURNAL OF SEX RESEARCH, 53(4-5), 363-391 (2016)}

2000; Kyrakanos, 1998; Rimer, 1993), and are dismissed as curious heterosexuals rather than authentic lesbians. The lesbian community has also historically distinguished between primary/born lesbians, whose same-sex sexuality is presumed to be more inborn and exclusive, and elective/ bisexual/political lesbians, whose same-sex sexuality is presumed more environmentally influenced and more bisexual (Burch, 1993; Golden, 1994; Ponse, 1978). In fact, the highest social regard within some lesbian communities has historically been granted to "gold star lesbians"- those who have never had sexual contact with a man (Queen, 1999; Whisman, 1993). At the opposite end of the spectrum, presumably, are heterosexually identified women who "perform" bisexuality in public settings to garner male attention (Fahs, 2009).

Clearly, both scientists and laypeople have observed that there are different types of sexual minorities, with different sexual developmental histories, different ratios of same-sex to other-sex attractions, different degrees of longitudinal stability in their attractions, and different perceptions regarding their capacity for sexual choice. Scientists studying sexual orientation do not know whether these differences correspond to differences in the causal pathways underlying same-sex sexuality (reviewed in Diamond, 2013; Diamond \& Wallen, 2011). For example, there is no evidence that someone with exclusive same-sex attractions is more "biologically gay" than someone with bisexual attractions. The reasons underlying diversity in the manifestations of same-sex sexuality are interesting and important from a scientific perspective, but they should be irrelevant as a matter of constitutional law. If an individual seeking to marry a same-sex partner is denied the right to do so, it matters little whether it is his first same-sex relationship or his 50th, whether he became aware of his same-sex attractions at age 10 or age 30, or whether he feels that his same-sex sexuality is innate or chosen. All that matters, from the perspective of civil rights, is whether he has the right to marry the partner of his choice.

When advocates for sexual-minority rights use the immutability of sexual orientation as a basis for protection from discrimination, they implicitly convey that the rights of some sexual minorities - the early-developing, exclusive, "gold star" types - are more deserving of protection than are others. Yet in the prescient words of Halley (1994), "[A]n adequate legal theory should protect the entire social class on whose behalf it is articulated" (p. 528). Individuals with complex, nonexclusive, unpredictable, confusing, or atypical patterns of same-sex and other-sex sexuality may face skepticism and marginalization from the broader LGBT community, but they deserve the same respect for their lives and relationships. As posited by Patricia Neal Warren (2009), "Shouldn't there be equal power and dignity for us in 'choosing' our orientation, rather than being assigned an orientation by chance?"

Such arguments are increasingly taken up under the banner of queer identity and queer theory. Although not a monolithic term, queer is typically used to signal a fundamental questioning and disruption of sexual categories and hierarchies, and to acknowledge the dynamic and flexible nature of sexuality (Butler, 1990; Duggan, 2006; Horner, 2007; Lovaas, Elia, \& Yep, 2007; Owens, 1998; Plummer, 2005, 2007; Rosky, 2013a; Sedgwick, 1990). Some research suggests that younger generations of sexual minorities are increasingly likely to describe their sexual identities as "queer" or to desist from sexual identity labels entirely (Savin-Williams, 2005). Other studies find that although younger cohorts of sexual-minority youth continue to adopt traditional identities such as lesbian, gay, or bisexual, they do so more critically and strategically than previous generations, acknowledging that such terms provide only a partial perspective on the complexity of their lived experiences (Russell, Clarke, \& Clary, 2009). If these historical shifts continue, we can expect that future generations of sexual minorities will increasingly use and perceive the terms lesbian, gay, and bisexual as heuristics, or mental "rules of thumb," rather than natural types. Individuals adopting this critical stance to sexual orientation and identity are likely to find immutability arguments inherently regressive, in that they reinforce the notion of natural, essential distinctions between 


\section{THE JOURNAL OF SEX RESEARCH, 53(4-5), 363-391 (2016)}

heterosexuals and homosexuals, rather than challenging the very existence of natural sexual categories.

Immutability arguments also fail to adequately serve the interests of sexual minorities from ethnic, cultural, or religious backgrounds that do not share the contemporary Western conceptualization of sexual orientation as a defining status designation. Such individuals may believe that their status as an ethnic or religious minority is more critical to their sense of selfhood than their status as a sexual minority, and that being "born Hawaiian" or "born Catholic" trumps being "born bisexual." Some research suggests that the "multiple marginalization" experiences of sexual and ethnic minorities lend themselves to more fluid and flexible notions of identity that can shift in response to changing social and community contexts (Chun \& Singh, 2010). Valdes (1997) has argued that the "ethnicization" of sexual orientation within legal and political discourse (i.e., the treatment of sexual orientation as a discrete and permanent trait akin to ethnicity, as discussed by Kimmel, 1993) often overshadows analyses of ethnic diversity within the sexual-minority population. Culture, class, and ethnicity powerfully shape the lived experiences of sexual minorities, influencing the manner in which they perceive and name same-sex desires; the meanings they craft of these desires; the opportunities, costs, and contexts of sexual behavior; and their very notion of an individual sexual self (Aranda et al., 2015; Consolacion et al., 2004; Jamil et al., 2009; Nazario, 2003; Parks et al., 2004; Rosario, Schrimshaw, \& Hunter, 2004). One telling example of the failure of conventional concepts of sexual orientation to represent the experiences of ethnic minorities comes from a study analyzing patterns of nonresponse across multiple waves of administration of the California Health Interview Survey (Jans et al., 2015). Different ethnic groups were differentially likely to skip the question about sexual orientation, and rates of nonresponse varied as a function of whether individuals completed the interview in their native language. Such data provide a potent reminder of the experiences that are literally missing from mainstream psychological discourses about sexual orientation. Thus, an additional reason to set aside immutability arguments for sexualminority rights is that these arguments sometimes obscure intersections between sexual identity and the dimensions of race, culture, ethnicity, religion, and social class, which give rise to unique and varied forms of sexual-minority experience.

\section{What Is Wrong With Being a Sexual Minority?}

A final and fatal weakness of immutability arguments for the rights of sexual minorities is that these arguments boil down to large-scale apologies or excuses for same-sex sexuality (Boucai, 2012; Schmeiser, 2009). In essence, they concede the point that same-sex sexuality is fundamentally inferior to heterosexuality and simply counter that sexual minorities cannot be punished for being born with their "condition" (Sullivan, 1995, p. 170). Indeed, research findings on genetic contributions to sexual orientation necessarily raise the specter of eugenics: Might gene therapy one day be used to "correct" sexual orientation, or might parents selectively terminate pregnancies on the basis of the child's sexual orientation (Greenberg \& Bailey, 2001; Sedgwick, 1990; Smith, 2014)? Regardless of whether such future scenarios are plausible, they underscore the degree to which immutability approaches to sexual-minority rights are fundamentally linked to-and hence fail to challenge-the social reprobation directed toward the "species" (Hammack et al., 2013) of homosexuality.

Immutability arguments also fail to challenge the longstanding anti-gay claim that society has an abiding interest in preventing the "spread" of same-sex sexuality, especially to children. The protection of children from same-sex sexuality has of course been a long-standing preoccupation of many anti-gay activists, who have argued that pro-gay policies and laws-including legalized samesex marriage-might make it more likely for children to grow up perceiving same-sex sexuality as a 


\section{THE JOURNAL OF SEX RESEARCH, 53(4-5), 363-391 (2016)}

legitimate life choice (Bork, 2004; Bryant, 1979). As reviewed by Rosky (2013b), the classic response by LGBT advocates has been that pro-gay legislation cannot possibly foster the "spread" of samesex sexuality, since sexual orientation is fixed at birth and impervious to environmental influence. This response is obviously scientifically problematic, as the foregoing scientific review demonstrates. Yet a deeper problem is that this response passively, implicitly accepts the premise that sexual orientation should be controlled.

This is the premise that activists should challenge, and not the likelihood of homosexual contagion. Quite simply, there is no legal or moral basis for states to "contain" same-sex sexuality and to actively promote and enforce heterosexuality among children and adults (see Rosky, 2013a, 2013b). Notably, some judges have already taken this position. In the California district court decision striking down Proposition 8, Chief Judge Vaughn Walker specifically addressed the question of whether the legalization of same-sex marriage might induce growing numbers of California children to adopt same-sex sexuality themselves and concluded that "California has no interest in asking gays and lesbians to change their sexual orientation or in reducing the numbers of gays and lesbians in California" (Perry v. Schwarzenegger, 2010, p. 967). The implications of this statement are profound, given that it starkly challenges the fundamental premise of anti-gay activism in the United States: that there is something wrong with same-sex sexuality. The very basis of immutability claims, as best expressed by Uganda's President Museveni, is that homosexuals should be punished for their sexual desires unless they can show that these desires are beyond their control.

We can turn this argument on its head_-and simultaneously make immutability claims irrelevant as preconditions for sexual-minority rights-by arguing that same-sex sexuality is nothing to punish. If there is no reason for societies to control and contain the expression of same-sex sexuality, then there is no reason to invoke scientific research on the nature and cause of same-sex sexuality to justify or challenge such policies.

\section{CONCLUSION}

In the landmark 1967 case Loving v. Virginia, the state of Virginia sought to defend the state's law against interracial marriage on the ground that "the scientific evidence" on miscegenation was "substantially in doubt" (p. 6). Of course, the Supreme Court rejected this argument. The Court famously held that "[u]nder our Constitution, the freedom to marry or not marry a person of another race resides with the individual and cannot be infringed by the State" (Loving v. Virginia, 1967 , p. 12). But in striking down laws against interracial marriage, the Court did not suggest that the individuals should be free to marry a person of another race because they "couldn't help" their attraction to other-race individuals or because they possessed an involuntary condition making it impossible for them to fall in love with same-race individuals. Rather, it was the fundamental freedom to marry a partner of one's choosing that was constitutionally protected.

We hold that the same logic applies to debates over same-sex marriage and ongoing debates about sexual-minority rights in the United States more generally. Now that the U.S. Constitution grants every individual the unfettered liberty to choose same-sex relationships, it simply does not matter why these choices are made and whether they were influenced by genes, hormones, society, or chance. To suggest that the dignity of a same-sex relationship depends on precisely what caused it is not only gratuitous but tragic. Like many other scholars across many other disciplines, we maintain sexual-minority rights that are framed as if they depend on scientific findings of immutable "conditions" are not worth fighting for.

\section{Acknowledgment}




\section{THE JOURNAL OF SEX RESEARCH, 53(4-5), 363-391 (2016)}

Dedicated to the memory of George A. Diamond

\section{References}

Academy of Science of South Africa. (2015). Diversity of sexuality: Implications for policy in Africa. Pretoria, South Africa: Academy of Science of South Africa.

Ackerman, B. (1985). Beyond Carolene Products. Yale Law Review, 98, 713-746.

Adkins-Regan, E. (2011). Neuroendocrine contributions to sexual partner preference in birds. Frontiers in Neuroendocrinology, 32(2), 155-163. doi:10.1016/j.yfrne.2011.01.003

American Psychological Association. (2008). Answers to your questions: For a better understanding of sexual orientation and homosexuality. Washington, DC: APA Press.

APATask Force on Appropriate Therapeutic Responses to Sexual Orientation. (2009). Report of the Task Force on Appropriate Therapeutic Responses to Sexual Orientation. Washington, DC: APA Press.

Aranda, F., Matthews, A. K., Hughes, T. L., Muramatsu, N., Wilsnack, S. C., Johnson, T. P., \& Riley, B. B. (2015). Coming out in color: Racial/ethnic differences in the relationship between level of sexual identity disclosure and depression among lesbians. Cultural Diversity and Ethnic Minority Psychology, 21(2), 247-257. doi:10.1037/a0037644

Baehr v. Lewin, 852 P.2d 44 (Haw. 1993).

Bailey, J. M. (2009). What is sexual orientation and do women have one? In D. A. Hope (Ed.), Nebraska symposium on motivation: Contemporary perspectives on lesbian, gay, and bisexual identities (Vol. 54, pp. 43-63). Lincoln: University of Nebraska Press.

Bailey, J. M., Rieger, G., \& Rosenthal, A. M. (2011). Still in search of bisexual sexual arousal: Comment on Cerny and Janssen (2011). Archives of Sexual Behavior, 40(6), 1293-1295. doi:10.1007/s10508-011-9778-5

Bailey, J. M., Vasey, P. L., Diamond, L. M., Breedlove, S. M., Vilain, E., \& Epprecht, M. (in press). Sexual orientation, controversy, and science. Psychological Science in the Public Interest.

Balsam, K. F., \& Mohr, J. J. (2007). Adaptation to sexual orientation stigma: A comparison of bisexual and lesbian/gay adults. Journal of Counseling Psychology, 54(3), 306-319. doi:10.1037/0022-0167.54.3.306

Bao, A.-M., \& Swaab, D. F. (2011). Sexual differentiation of the human brain: Relation to gender identity, sexual orientation, and neuropsychiatric disorders. Frontiers in Neuroendocrinology, 32(2), 214-226. doi:10.1016/j.yfrne.2011.02.007 


\section{THE JOURNAL OF SEX RESEARCH, 53(4-5), 363-391 (2016)}

Baum, M. J. (2006). Mammalian animal models of psychosexual differentiation: When is "translation" to the human situation possible? Hormones and Behavior, 50(4), 579-588. doi:10.1016/j.yhbeh.2006.06.003

Baumeister, R. F., \& Twenge, J. M. (2002). Cultural suppression of female sexuality. Review of General Psychology, 6(2), 166-203. doi:10.1037/1089-2680.6.2.166

BBC News. (2014, February 22). Uganda: Museveni "seeks U.S. advice on homosexuality." Retrieved from http://www.bbc.com/news/worldafrica-26297356

Bell, A. P., Weinberg, M. S., \& Hammersmith, S. K. (1981). Sexual preference: Its development in men and women. Bloomington: Indiana University Press.

Bering, J. (2013, June 17). Stop saying “sexual preference.” Slate.

Blackwood, E. (2000). Culture and women's sexualities. Journal of Social Issues, 56(2), 223-238. doi:10.1111/0022-4537.00162

Boardman, J. D., Blalock, C. L., \& Pampel, F. C. (2010). Trends in the genetic influences on smoking. Journal of Health and Social Behavior, 51(1), 108-123. doi:10.1177/0022146509361195

Bork, R. H. (2004, August). The necessary amendment. First Things. Retrieved from http://www.firstthings.com/article/2004/08/the-necessary-amendment

Borowich, A. E. (2008). Failed reparative therapy of Orthodox Jewish homosexuals. Journal of Gay and Lesbian Mental Health, 12(3), 167-177. doi:10.1080/19359700802111072

Boucai, M. (2012). Sexual liberty and same-sex marriage: An argument from bisexuality. San Diego Law Review, 49(2), 415-486.

Bouchard, K. N., Timmers, A. D., \& Chivers, M. L. (2015). Genderspecificity of genital response and self-reported sexual arousal in women endorsing facets of bisexuality. Journal of Bisexuality, 15(2), 180-203. doi:10.1080/15299716.2015.1022924

Bowen v. Gilliard, 483 U.S. 587 (1987).

Bowers v. Hardwick, 478 U.S. 186 (1986).

Bradner, E., \& Jaffee, A. (2015, March 5). Ben Carson apologizes for comments on gay people. CNN Politics. Retrieved from http://www.cnn.com/2015/03/04/politics/ben-carson-prisons-gaychoice/

Bradshaw, K., Dehlin, J. P., Crowell, K. A., Galliher, R. V., \& Bradshaw, W. S. (2015). Sexual orientation change efforts through psychotherapy for LGBQ individuals affiliated with the Church of Jesus Christ of Latter-Day Saints. Journal of Sex and Marital Therapy, 41(4), 391-412. doi:10.1080/0092623X.2014.915907 


\section{THE JOURNAL OF SEX RESEARCH, 53(4-5), 363-391 (2016)}

Brief on the Merits for Respondent the Bipartisan Legal Advisory Group of the U.S. House of Representatives, United States v. Windsor, 133 S.Ct. 2675 (2013).

Bruni, F. (2012, January 28). Genetic or not, gay won't go away. New York Times. Retrieved from http://www.nytimes.com/2012/01/29/opinion/sunday/bruni-gay-wont-go-away-genetic-ornot.html?ref=topics\&_r=1

Bryant, A. (1979). The Anita Bryant Story: The survival of our nation's families and the threat of militant homosexuality. Grand Rapids, MI: Fleming, H. Revell.

Burch, B. (1993). On intimate terms: The psychology of difference in lesbian relationships. Chicago: University of Illinois Press.

Burnett, D. (2015, January 8). Why would people "choose" to be gay? The Guardian. Retrieved from http://www.theguardian.com/science/brainflapping/2015/jan/08/homosexuality-gay-choicepsychology

Burr, C. (1996). A separate creation: The search for the biological origins of sexual orientation. New York, NY: Hyperion.

Busseri, M. A.,Willoughby, T., Chalmers, H., \& Bogaert, A. R. (2006). Same-sex attraction and successful adolescent development. Journal of Youth and Adolescence, 35(4), 561-573.

doi:10.1007/s10964-006-9071-4

Butler, J. P. (1990). Gender trouble: Feminism and the subversion of identity. London, UK:

Routledge.

Callis, A. S. (2013). The black sheep of the pink flock: Labels, stigma, and bisexual identity. Journal of Bisexuality, 13(1), 82-105. doi:10.1080/15299716.2013.755730

Caramagno, T. C. (2002). Irreconcilable differences? Intellectual stalemate in the gay rights debate. Westport, CT: Praeger.

Cardoso, F. L., \& Werner, D. (2013). Same-sex behavior of heterosexual men: A cross-cultural comparison. Journal of Bisexuality, 13(3), 310-328. doi:10.1080/15299716.2013.813000

Case, M. A. (2010). What feminists have to lose in same-sex marriage litigation. University of California at Los Angeles Law Review, 57, 1199-1233.

Chakraborty, A., McManus, S., Brugha, T. S., Bebbington, P., \& King, M. (2011). Mental health of the non-heterosexual population of England. British Journal of Psychiatry, 198(2), 143-148. doi:10.1192/bjp.bp.110.082271

Chan, C. S. (1995). Issues of sexual identity in an ethnic minority: The case of Chinese American lesbians, gay men, and bisexual people. In A. R. D'Augelli \& C. J. Patterson (Eds.), Lesbian, gay, and bisexual identities over the lifespan: Psychological perspectives (pp. 87-101). New

York, NY: Oxford University Press. 


\section{THE JOURNAL OF SEX RESEARCH, 53(4-5), 363-391 (2016)}

Chandra, A., Mosher, W. D., Copen, C., \& Sionean, C. (2011). Sexual behavior, sexual attraction, and sexual identity in the United States: Data from the 2006-2008 National Survey of Family Growth. National Health Statistics Reports, 3(36), 1-36. doi:10.1007/978-94-007-5512-3_4

Charney, E. (2012). Behavior genetics and postgenomics. Behavioral and Brain Sciences, 35(5), 331358. doi:10.1017/S0140525X11002226

Chivers, M. L., \& Bailey, J. M. (2005). A sex difference in features that elicit genital response. Biological Psychology, 70(2), 115-120. doi:10.1016/j.biopsycho.2004.12.002

Chivers, M. L., Rieger, G., Latty, E., \& Bailey, J. M. (2004). A sex difference in the specificity of sexual arousal. Psychological Science, 15, 736-744. doi:10.1111/j.0956-7976.2004.00750.x

Chivers, M. L., Seto, M. C., \& Blanchard, R. (2007). Gender and sexual orientation differences in sexual response to sexual activities versus gender of actors in sexual films. Journal of Personality and Social Psychology, 93(6), 1108-1121. doi:10.1037/0022-3514.93.6.1108

Chivers, M. L., Seto, M. C., Lalumiere, M. L., Laan, E., \& Grimbos, T. (2010). Agreement of selfreported and genital measures of sexual arousal in men and women: A meta-analysis. Archives of Sexual Behavior, 39(1), 5-56. doi:10.1007/s10508-009-9556-9

Chivers, M. L., \& Timmers, A. D. (2012). Effects of gender and relationship context in audio narratives on genital and subjective sexual response in heterosexual women and men. Archives of Sexual Behavior, 41(1), 185-197. doi:10.1007/s10508-012-9937-3

Chun, K. Y. S., \& Singh, A. A. (2010). The bisexual youth of color intersecting identities development model: A contextual approach to understanding multiple marginalization experiences. Journal of Bisexuality, 10(4), 429-451. doi:10.1080/15299716.2010.521059 The Church of Jesus Christ of Latter-Day Saints. (2012). Love one another: A discussion of same-gender attraction. Retrieved from http://mormonsandgays.org/

Clarke, J. (2015). Against immutability. Yale Law Review, 125, 2-102.

Consolacion, T. B., Russell, S. T., \& Sue, S. (2004). Sex, race/ethnicity, and romantic attractions: Multiple minority status adolescents and mental health. Cultural Diversity and Ethnic Minority Psychology, 10(3), 200-214. doi:10.1037/1099-9809.10.3.200

Copland, S. (2014, April 21). What's wrong with choosing to be gay, anyway? The Guardian. Retrieved from http://www.theguardian.com/commentisfree/2014/apr/21/whats-wrong-withchoosing-to-begay\#img-1]

Copland, S. (2015, July 10). Born this way? Society, sexuality, and the search for the "gay gene." The Guardian. Retrieved from http://www.theguardian.com/science/blog/2015/jul/10/born-this-waysociety-sexuality-gay-gene

Cramer, R. J., Chevalier, C., Gemberling, T. M., Stroud, C. H., \& Graham, J. (2015). A confirmatory factor analytic evaluation of the Klein Sexual Orientation Grid. Psychology of Sexual Orientation and Gender Diversity, 2(2), 123-129. doi:10.1037/sgd0000102 Davis, A. (2000). Confessions of a 


\section{THE JOURNAL OF SEX RESEARCH, 53(4-5), 363-391 (2016)}

LUG. Alternet, April 25, 2000. Retreived from

http://www.alternet.org/story/1256/confessions_of_a_l.u.g.

Dawood, K., Bailey, J. M., \& Martin, N. G. (2009). Genetic and environmental influences on sexual orientation. In Y.-K. Kim (Ed.), Handbook of behavior genetics (pp. 269-279). New York, NY: Springer Science + Business Media.

deBoer, F. (2015, July 3). The "born this way" argument cheapens marriage equality victory. The Observer. Retrieved from http://observer.com/2015/07/the-born-this-way-argument-cheapensmarriage-equality-victory/

Dehlin, J. P., Galliher, R. V., Bradshaw, W. S., Hyde, D. C., \& Crowell, K. A. (2015). Sexual orientation change efforts among current or former LDS Church members. Journal of Counseling Psychology, 62(2), 95-105. doi:10.1037/cou0000011

De Leon v. Perry, 975 F.Supp.2d 632 (W.D. Tex 2014).

D’Emilio, J. (1983). Capitalism and gay identity. In D. Morton (Ed.), The material queer: A lesbigay cultural studies reader (pp. 467-475). Boulder, CO: Westview Press.

Diamond, L. M. (2003). What does sexual orientation orient? A biobehavioral model distinguishing romantic love and sexual desire. Psychological Review, 110, 173-192. doi:10.1037/0033-

295X.110.1.173

Diamond, L. M. (2007). A dynamical systems approach to the development and expression of female same-sex sexuality. Perspectives on Psychological Science, 2(2), 142-161.

doi:10.1111/ppsc.2007.2.issue-2

Diamond, L. M. (2008a). Female bisexuality from adolescence to adulthood: Results from a 10 year longitudinal study. Developmental Psychology, 44, 5-14. doi:10.1037/0012-1649.44.1.5

Diamond, L. M. (2008b). Sexual fluidity: Understanding women's love and desire. Cambridge, MA: Harvard University Press. Diamond, L. M. (2012). The desire disorder in research on sexual orientation in women: Contributions of dynamical systems theory. Archives of Sexual Behavior, 41, 73-83. doi:10.1007/s10508-012-9909-7

Diamond, L. M. (2013). Concepts of female sexual orientation. In C. P. Patterson \& A. R. D’Augelli (Eds.), Handbook of psychology and sexual orientation (pp. 3-17). New York, NY: Oxford University Press.

Diamond, L. M., Butterworth, M. R., \& Savin-Williams, R. C. (2010). Working with sexual-minority individuals. In D. H. Barlow (Ed.), Oxford handbook of clinical psychology (pp. 837-867). New York, NY: Oxford University Press.

Diamond, L. M., \& Dickenson, J. A. (2012). The neuroimaging of love and desire: Review and future directions. Clinical Neuropsychiatry, 9(1), 39-46. 


\section{THE JOURNAL OF SEX RESEARCH, 53(4-5), 363-391 (2016)}

Diamond, L. M., \& Wallen, K. (2011). Sexual-minority women's sexual motivation around the time of ovulation. Archives of Sexual Behavior, 40, 237-246. doi:10.1007/s10508-010-9631-2

Dickson, N., Paul, C., \& Herbison, P. (2003). Same-sex attraction in a birth cohort: Prevalence and persistence in early adulthood. Social Science and Medicine, 56, 1607-1615. doi:10.1016/S02779536(02)00161-2

Dickson, N., Roode, T., Cameron, C., \& Paul, C. (2013). Stability and change in same-sex attraction, experience, and identity by sex and age in a New Zealand birth cohort. Archives of Sexual Behavior, 42, 753-763. doi:10.1007/s10508-012-0063-z

Dodge, B., \& Sandfort, T. G. M. (2007). A review of mental health research on bisexual individuals when compared to homosexual and heterosexual individuals. In B. A. Firestein \& B. A. Firestein (Eds.), Becoming visible: Counseling bisexuals across the lifespan (pp. 28-51). New York, NY: Columbia University Press.

Drabant, E. M., Kiefer, A. K., Eriksson, N., Mountain, J. L., Francke, U., Tung, J. Y., \& Do, C. B. (2012, November). Genome-wide association study of sexual orientation in a large, web-based cohort. Poster presented at the annual meeting of the American Society of Human Genetics, San Francisco, CA. Retrieved from http://blog.23andme.com/wp-content/uploads/2012/11/DrabantPoster-v7.pdf

Duggan, L. (2006). The discipline problem: Queer theory meets lesbian and gay history. In N. D. Hunter (Ed.), Sex wars: Sexual dissent and political culture (10th anniversary ed., pp. 185-195). New York, NY: Routledge.

Emens, E. (2014). Compulsory sexuality. Stanford Law Review, 66, 303-386. Equality Foundation of Greater Cincinnati v. City of Cincinnati, 54 F.3d 261 (6th Cir. 1995).

Eskridge, W. (2008). Dishonorable passions: Sodomy laws in America, 1861-2003. New York, NY: Viking.

Fahs, B. (2009). Compulsory bisexuality? The challenges of modern sexual fluidity. Journal of Bisexuality, 9(3-4), 431-449. doi:10.1080/15299710903316661

Falomir-Pichastor, J. M., \& Hegarty, P. (2014). Maintaining distinctions under threat: Heterosexual men endorse the biological theory of sexuality when equality is the norm. British Journal of Social Psychology, 53(4), 731-751. doi:10.1111/bjso.12051

Feldblum, C. R. (2005). Gay is good: The moral case for marriage equality and more. Yale Journal of Law \& Feminism, 17, 139-184.

Ferreira, P. H., Beckenkamp, P., Maher, C. G., Hopper, J. L., \& Ferreira, M. L. (2013). Nature or nurture in low back pain? Results of a systematic review of studies based on twin samples. European Journal of Pain, 17(7), 957-971. doi:10.1002/j.1532-2149.2012.00277.x 


\section{THE JOURNAL OF SEX RESEARCH, 53(4-5), 363-391 (2016)}

Firestein, B. A. (1996). Bisexuality as paradigm shift: Transforming our disciplines. In B. A. Firestein \& B. A. Firestein (Eds.), Bisexuality:The psychology and politics of an invisible minority (pp. 263291). Thousand Oaks, CA: Sage.

Ford, Z. (2015, October 29). Ben Carson says he is not a homophobe. Ben Carson disagrees. ThinkProgress. Retrieved from http://thinkprogress.org/lgbt/2015/10/29/3717304/ben-carsonhomophobia/

Foucault, M. (1980). The history of sexuality (Vol. I). New York, NY: Vintage.

Freud, S. (1920). Three contributions to the theory of sex. New York, NY: Nervous and Mental Disease Publishing Company.

Frontiero v. Richardson, 411 U.S. 677 (1973).

Gartrell, N. K., \& Bos, H. M. W. (2010). U.S. National Longitudinal Lesbian Family Study: Psychological adjustment of 17-year-old adolescents. Pediatrics, 126(1), 28-36. doi:10.1542/peds.2009-3153

Gartrell, N. K., Bos, H. M. W., \& Goldberg, N. G. (2011). Adolescents of the U.S. National Longitudinal Lesbian Family Study: Sexual orientation, sexual behavior, and sexual risk exposure. Archives of Sexual Behavior, 40(6), 1199-1209. doi:10.1007/s10508-010-9692-2

Gates, G. J. (2011, April). How many people are lesbian, gay, bisexual, and transgender? Los Angeles, CA: The Williams Institute.

Gerstmann, E. (1999). The constitutional underclass: Gays, lesbians, and the failure of class-based equal protection. Chicago, IL: University of Chicago Press.

Ghose, T. (2015, March 5). Being gay is not a choice: Science contradicts Ben Carson. LiveScience. Retrieved from http://www.livescience.com/50058-being-gay-not-a-choice.html

Golden, C. (1987). Diversity and variability in women's sexual identities. In Boston Lesbian Psychologies Collective (Ed.), Lesbian psychologies: Explorations and challenges (pp. 19-34). Urbana: University of Illinois Press.

Golden, C. (1994). Our politics and choices: The feminist movement and sexual orientation. In B. Greene \& G. M. Herek (Eds.), Lesbian and gay psychology: Theory, research, and clinical applications (pp. 54-70). Thousand Oaks, CA: Sage.

Golden, C. (1996). What's in a name? Sexual self-identification among women. In R. C. SavinWilliams \& K. M. Cohen (Eds.), The lives of lesbians, gays, and bisexuals: Children to adults (pp. 229-249). Fort Worth, TX: Harcourt Brace.

Goodridge v. Department of Public Health, 798 N.E.2d 941 (Mass. 2003). 


\section{THE JOURNAL OF SEX RESEARCH, 53(4-5), 363-391 (2016)}

Goodstein, L. (2015, November 6). Mormons sharpen stance against same-sex marriage. New York Times. Retrieved from http://www.nytimes.com/2015/11/07/us/mormons-gaymarriage.html?_r=0

Gooren, L. (2006). The biology of human psychosexual differentiation. Hormones and Behavior, 50(4), 589-601. doi:10.1016/j.yhbeh.2006.06.011

Gorman, B. K., Denney, J. T., Dowdy, H., \& Medeiros, R. A. (2015). A new piece of the puzzle: Sexual orientation, gender, and physical health status. Demography, 52, 1357-1382. doi:10.1007/s13524-015-0406-1

Graham v. Richardson, 403 U.S. 365 (1971).

Greenberg, A. S., \& Bailey, J. M. (2001). Parental selection of children's sexual orientation. Archives of Sexual Behavior, 30(4), 423-437. doi:10.1023/A:1010265416676

Halberstam, J. (2005). In a queer time and place: Transgender bodies, subcultural lives. New York: NYU Press.

Halley, J. E. (1994). Sexual orientation and the politics of biology: A critique of the argument from immutability. Stanford Law Review, 46, 503-568. doi:10.2307/1229101

Halley, J. E. (1998). Gay rights and identity imitation: Issues in the ethics of representation. In D. Kairys (Ed.), The politics of law: A progressive critique (3rd ed., pp. 115-146). New York, NY: Basic Books.

Halsam, N., \& Levy, S. R. (2006). Essentialist beliefs about homosexuality: Structure and implications for prejudice. Personality and Social Psychology Bulletin, 32, 471-485. doi:10.1177/0146167205276516

Hamann, S., Herman, R. A., Nolan, C. L., \& Wallen, K. (2004). Men and women differ in amygdala response to visual sexual stimuli. Nature Neuroscience, 7(4), 411-416. doi:10.1038/nn1208

Hammack, P. L., Mayers, L., \& Windell, E. P. (2013). Narrative, psychology, and the politics of sexual identity in the United States: From "sickness" to "species" to "subject." Psychology and Sexuality, 4(3), 219-243. doi:10.1080/19419899.2011.621131

Hammack, P. L., \& Windell, E. P. (2011). Psychology and the politics of same-sex desire in the United States: An analysis of three cases. History of Psychology, 14(3), 220-248.

doi:10.1037/a0024541

Hayes, J., Chakraborty, A. T., McManus, S., Bebbington, P., Brugha, T., Nicholson, S., \& King, M. (2012). Prevalence of same-sex behavior and orientation in England: Results from a national survey. Archives of Sexual Behavior, 41, 631-639. doi:10.1007/s10508-011-9856-8

Hegarty, P., \& Golden, A. M. (2008). Attributional beliefs about the controllability of stigmatized traits: Antecedents or justifications of prejudice? Journal of Applied Social Psychology, 38(4), 10231044. doi:10.1111/j.1559-1816.2008.00337.x 


\section{THE JOURNAL OF SEX RESEARCH, 53(4-5), 363-391 (2016)}

Hegarty, P., \& Pratto, F. (2001). Sexual orientation beliefs: Their relationship to anti-gay attitudes and biological determinism. Journal of Homosexuality, 41(1), 121-135. doi:10.1300/J082v41n01_04

Henley, C. L., Nunez, A. A., \& Clemens, L. G. (2011). Hormones of choice: The neuroendocrinology of partner preference in animals. Frontiers in Neuroendocrinology, 32(2), 146154. doi:10.1016/j.yfrne.2011.02.010

Herbenick, D., Reece, M., Schick, V., Sanders, S. A., Dodge, B., \& Fortenberry, J. D. (2010). Sexual behavior in the United States: Results from a national probability sample of men and women ages 14-94. Journal of Sexual Medicine, 7(Suppl. 5), 255-265. doi:10.1111/j.1743-6109.2010.02012.x

Herdt, G. (1990). Developmental discontinuities and sexual orientation across cultures. In D. P. McWhirter, S. A. Sanders, \& J. M. Reinisch (Eds.), Homosexuality/heterosexuality: Concepts of sexual orientation (pp. 208-236). New York, NY: Oxford University Press.

Herdt, G., \& Boxer, A. (1995). Bisexuality: Toward a comparative theory of identities and culture. In R. G. Parker, J. H. Gagnon, R. G. Parker, \& J. H. Gagnon (Eds.), Conceiving sexuality: Approaches to sex research in a postmodern world (pp. 69-83). Florence, KY: Routledge.

Herek, G. M., Norton, A. T., Allen, T. J., \& Sims, C. L. (2010). Demographic, psychological, and social characteristics of self-identified lesbian, gay, and bisexual adults in a U.S. probability sample. Sexuality Research and Social Policy, 7, 176-200. doi:10.1007/s13178-010-0017-y

High Tech Gays v. Defense Industry Security Clearance Office, 895 F.2d 563 (9th Cir. 1990).

Hill, A. K., Dawood, K., \& Puts, D. A. (2013). Biological foundations of sexual orientation. In C. J. Patterson, A. R. D'Augelli, C. J. Patterson, \& A. R. D'Augelli (Eds.), Handbook of psychology and sexual orientation (pp. 55-68). New York, NY: Oxford University Press.

Hines, M. (2004). Androgen, estrogen, and gender: Contributions of the early hormone environment to gender-related behavior. In A. H. Eagly, A. E. Beall, \& R. J. Sternberg (Eds.), The psychology of gender (2nd ed., pp. 9-37). New York, NY: Guilford Press.

Hines, M. (2011). Prenatal endocrine influences on sexual orientation and on sexually differentiated childhood behavior. Frontiers in Neuroendocrinology, 32(2), 170-182.

doi:10.1016/j.yfrne.2011.02.006

Horner, E. (2007). Queer identities and bisexual identities: What's the difference? In B. A. Firestein (Ed.), Becoming visible: Counseling bisexuals across the lifespan (pp. 287-296). New York, NY:

Columbia University Press.

Hubbard, K., \& Hegarty, P. (2014). Why is the history of heterosexuality essential? Beliefs about the history of sexuality and their relationship to sexual prejudice. Journal of Homosexuality, 61(4), 471490. doi:10.1080/00918369.2014.865448

Hyde, J. S. (2005). The genetics of sexual orientation. In J. S. Hyde (Ed.), Biological substrates of human sexuality (pp. 9-20). Washington, DC: APA Press. 


\section{THE JOURNAL OF SEX RESEARCH, 53(4-5), 363-391 (2016)}

Igartua, K., Thombs, B. D., Burgos, G., \& Montoro, R. (2009). Concordance and discrepancy in sexual identity, attraction, and behavior among adolescents. Journal of Adolescent Health, 45(6), 602-608. doi:10.1016/j.jadohealth.2009.03.019

Jamil, O. B., Harper, G. W., \& Fernandez, M. I. (2009). Sexual and ethnic identity development among gay-bisexual-questioning (GBQ) male ethnic minority adolescents. Cultural Diversity and Ethnic Minority Psychology, 15(3), 203-214. doi:10.1037/a0014795

Jans, M., Viana, J., Grant, D., Cochran, S. D., Lee, A. C., \& Ponce, N. A. (2015). Trends in sexual orientation missing data over a decade of the California Health Interview Survey. American Journal of Public Health, 105(5), e43-e50. doi:10.2105/AJPH.2014.302514

Jocklin, V., McGue, M., \& Lykken, D. T. (1996). Personality and divorce: A genetic analysis. Journal of Personality and Social Psychology, 71 (2), 288-299. doi:10.1037/0022-3514.71.2.288

Jones, S., \& Yarhouse, M. (2011). A longitudinal study of attempted religiously mediated sexual orientation change. Journal of Sex and Marital Therapy, 37(5), 404-427.

doi:10.1080/0092623X.2011.607052

Jordan-Young, R. M. (2010). Brain storm: The flaws in the science of sex differences. Cambridge, MA: Harvard University Press.

Jordan-Young, R. M. (2012). Hormones, context, and "brain gender": A review of evidence from congenital adrenal hyperplasia. Social Science and Medicine, 74(11), 1738-1744. doi:10.1016/j. socscimed.2011.08.026

Kaestle, C. E., \& Ivory, A. H. (2012). A forgotten sexuality: Content analysis of bisexuality in the medical literature over two decades. Journal of Bisexuality, 12, 35-48.

doi:10.1080/15299716.2012.645701

Kerrigan v. Commission of Public Health, 957 A.2d 407 (Conn. 2008).

Keski-Rahkonen, A., Bulik, C. M., Neale, B. M., Rose, R. J., Rissanen, A., \& Kaprio, J. (2005). Body dissatisfaction and drive for thinness in young adult twins. International Journal of Eating Disorders, 37(3), 188-199. doi:10.1002/eat.20138

Khan, S. (2015, July 23). Not born this way. Aeon. Retrieved from https://aeon.co/essays/whyshould-gay-rights-depend-on-being-born-this-way

Kimmel, M. S. (1993). Sexual balkanization: Gender and sexuality as the new ethnicities. Social Research, 60(3), 571-587.

Kitchen v. Herbert, 755 F.3d 1193 (Utah 2013).

Kitzinger, C. (1997). Lesbian and gay psychology: A critical analysis. In D. Fox \& I. Prilleltensky (Eds.), Critical psychology: An introduction (pp. 202-216). Thousand Oaks, CA: Sage. 


\section{THE JOURNAL OF SEX RESEARCH, 53(4-5), 363-391 (2016)}

Kitzinger, C., \& Coyle, A. (1995). Lesbian and gay couples: Speaking of difference. The Psychologist, 8, 64-69.

Klein, F., Sepekoff, B., \& Wolf, T. J. (1985). Sexual orientation: A multivariable dynamic process. In F. Klein \& T. Wolf (Eds.), Two lives to lead: Bisexuality in men and women (pp. 35-49).

Binghamton, NY: Harrington Park Press.

Kleinplatz, P. J., \& Diamond, L. M. (2013). Sexual diversity. In D. L. Tolman \& L. M. Diamond (Eds.), APA handbook on psychology and sexuality (pp. 245-267). Washington, DC: APA Press.

Korematsu v. United States, 323 U.S. 214 (1944).

Kuhle, B. X., \& Radke, S. (2013). Born both ways: The alloparenting hypothesis for sexual fluidity in women. Evolutionary Psychology, 11, 304-323. doi:10.1177/147470491301100202

Kuyper, L., \& Vanwesenbeeck, I. (2009). High levels of same-sex experiences in the Netherlands: Prevalences of same-sex experiences in historical and international perspective. Journal of Homosexuality, 56 (8), 993-1010. doi:10.1080/00918360903275401

Kyrakanos, J. (1998). LUGgin' It. InsideOUT Magazine, 9.

Landén, M., \& Innala, S. (2002). The effect of a biological explanation on attitudes towards homosexual persons. A Swedish national sample study. Nordic Journal of Psychiatry, 56(3), 181186. doi:10.1080/080394802317607156

Latta v. Otter, 771 F.3d 456 (9nd Cir. 2014).

Laumann, E. O., Gagnon, J. H., Michael, R. T., \& Michaels, F. (1994). The social organization of sexuality: Sexual practices in the United States. Chicago, IL: University of Chicago Press.

Lawrence v. Texas, 539 U.S. 558 (2003).

Lessov-Schlaggar, C. N., Kristjansson, S. D., Bucholz, K. K., Heath, A. C., \& Madden, P. A. F. (2012). Genetic influences on developmental smoking trajectories. Addiction, 107(9), 1696-1704. doi:10.1111/j.1360-0443.2012.03871.x

Letter to the president of Uganda. (2014, February 3). Washington Post. Retrieved from http://www.washingtonpost.com/r/2010-2019/WashingtonPost/2014/02/10/EditorialOpinion/Graphics/LetterPresidentMuseveni.pdf

LeVay, S. (2011). Gay, straight, and the reason why: The science of sexual orientation. New York, NY: Oxford University Press.

Lewis, G. B. (2009). Does believing homosexuality is innate increase support for gay rights? Policy Studies Journal, 37(4), 669-693. doi:10.1111/j.1541-0072.2009.00330.x 


\section{THE JOURNAL OF SEX RESEARCH, 53(4-5), 363-391 (2016)}

Lhomond, B., Saurel-Cubizolles, M.-J., \& Michaels, S. (2014). A multidimensional measure of sexual orientation, use of psychoactive substances, and depression: Results of a national survey on sexual behavior in France. Archives of Sexual Behavior, 43(3), 607-619. doi:10.1007/s10508-013-0124-y

Lovaas, K. E., Elia, J. P., \& Yep, G. A. (Eds.). (2007). LGBT studies and queer theory: New conflicts, collaborations, and contested terrain. New York, NY: Routledge.

Love v. Beshear, 989 F.Supp.2d 536 (W.D. Kent 2014).

Loving v. Virginia, 388 U.S. 1 (1967).

Lyng v. Castillo, 477 U.S. 635 (1988).

Marriage Cases, 183 P.3d 384 (Cal. 2008).

Matthews, D. D., Blosnich, J. R., Farmer, G. W., \& Adams, B. J. (2014). Operational definitions of sexual orientation and estimates of adolescent health risk behaviors. LGBT Health, 1(1), 42-49. doi:10.1089/lgbt.2013.0002

McHugh, P. (2013). Brief of amicus curiae concerning the immutability of sexual orientations in support of affirmance on the merits, Windsor, 133 S. Ct. 2675 (Nos. 12-307).

McLean, R. (2003). Deconstructing Black gay shame: A multicultural perspective on the quest for a healthy ethnic and sexual identity. In G. Roysircar, D. S. Sandhu, \& V. E. S. Bibbins (Eds.), Multicultural competencies: A guidebook of practices (pp. 109-118). Alexandria, VA: Association for Multicultural Counseling \& Development.

Mercer, C. H., Tanton, C., Prah, P., Erens, B., Sonnenberg, P., Clifton, S., \& Johnson, A. M. (2013). Changes in sexual attitudes and lifestyles in Britain through the life course and over time: Findings from the National Survey of Sexual Attitudes and Lifestyles (Natsal). The Lancet, 382(9907), 1781-1794. doi:10.1016/S0140-6736(13)62035-8

Meyer-Bahlburg, H. F. L., Dolezal, C., Baker, S. W., \& New, M. I. (2008). Sexual orientation in women with classical or non-classical congenital adrenal hyperplasia as a function of degree of prenatal androgen excess. Archives of Sexual Behavior, 37(1), 85-99. doi:10.1007/s10508-007-92651

Minter, S. P. (2012). Supporting transgender children: New legal, social, and medical approaches. Journal of Homosexuality, 59(3), 422-433. doi:10.1080/00918369.2012.653311

Mock, S. E., \& Eibach, R. P. (2012). Stability and change in sexual orientation identity over a 10-year period in adulthood. Archives of Sexual Behavior, 41, 641-648. doi:10.1007/s10508-011-9761-1

Mondimore, F. M. (1996). A natural history of homosexuality. Baltimore, MD: Johns Hopkins University Press.

Money, J. (1987). Sin, sickness, or status? Homosexual gender identity and psychoneuroendocrinology. American Psychologist, 42, 384-399. doi:10.1037/0003-066X.42.4.384 


\section{THE JOURNAL OF SEX RESEARCH, 53(4-5), 363-391 (2016)}

Money, J. (1988). Gay, straight, and in-between: The sexology of erotic orientation. New York, NY: Oxford University Press.

Mosher, W. D., Chandra, A., \& Jones, J. (2005). Sexual behavior and selected health measures: Men and women 15-44 years of age, United States, 2002. Advance data from vital and health statistics (No. 362, pp, 1-56). Hyattsville, MD: National Center for Health Statistics.

Mucciaroni, G., \& Killian, M. L. (2004). Immutability, science, and legislative debate over gay, lesbian, and bisexual rights. Journal of Homosexuality, 47(1), 53-77. doi:10.1300/J082v47n01_04

Murray, S. O. (2000). Homosexualities. Chicago, IL: University of Chicago Press.

Muscarella, F. (1999). The homoerotic behavior that never evolved. Journal of Homosexuality, 37(3), 1-18. doi:10.1300/J082v37n03_01

Mustanski, B. S., Birkett, M., Greene, G. J., Rosario, M., Bostwick, W., \& Everett, B. G. (2014). The association between sexual orientation identity and behavior across race/ethnicity, sex, and age in a probability sample of high school students. American Journal of Public Health, 104(2), 237-244. doi:10.2105/AJPH.2013.301451

Mustanski, B. S., Chivers, M. L., \& Bailey, J. M. (2002). A critical review of recent biological research on human sexual orientation. Annual Review of Sex Research, 13, 89-140.

Mustanski, B. S., Dupree, M. G., Nievergelt, C. M., Bocklandt, S., Schork, N. J., \& Hamer, D. H. (2005). A genomewide scan of male sexual orientation. Human Genetics, 116, 272-278.

doi:10.1007/s00439-004-1241-4

Mustanski, B. S., Van Wagenen, A., Birkett, M., Eyster, S., \& Corliss, H. L. (2014). Identifying sexual orientation health disparities in adolescents: Analysis of pooled data from the Youth Risk Behavior Survey, 2005 and 2007. American Journal of Public Health, 104(2), 211-217.

doi:10.2105/AJPH.2013.301748

Nazario, A. (2003). Latino cross-cultural same-sex male relationships: Issues of ethnicity, race, and other domains of influence. In V. Thomas, T. A. Karis, \& J. L. Wetchler (Eds.), Clinical issues with interracial couples: Theories and research (pp. 103-113). Binghamton, NY: Haworth Press.

Ngun, T. C., Guo, W., Ghahramani, N. M., Purkayastha, K., Conn, D., Sanchez, F. J., \& Vilain, E. (2015, October). A novel predictive model of sexual orientation using epigenetic markers. Paper presented at the annual meeting of the American Society of Human Genetics, Baltimore, MD.

Ngun, T. C., \& Vilain, E. (2014). The biological basis of human sexual orientation: Is there a role for epigenetics? Advances in Genetics, 86, 167-184. doi:10.1016/B978-0-12-800222-3.00008-5

Oaks, D. H. (1995, October). Same-gender attraction. Ensign. Retrieved from https://www.lds.org/ensign/1995/10/same-gender-attraction?lang=eng

Obergefell v. Hodges, 576 U.S. ___(slip. op.) (2015). 


\section{THE JOURNAL OF SEX RESEARCH, 53(4-5), 363-391 (2016)}

Obergefell v. Wymyslo, 962 F.Supp.2d 968 (W.D. Ohio 2013).

Oldham, J. D., \& Kasser, T. (1999). Attitude change in response to information that male homosexuality has a biological basis. Journal of Sex and Marital Therapy, 25(2), 121-124. doi:10.1080/00926239908403984

Ott, M. Q., Corliss, H. L., Wypij, D., Rosario, M., \& Austin, S. B. (2011). Stability and change in selfreported sexual orientation identity in young people: Application of mobility metrics. Archives of Sexual Behavior, 40(3), 519-532. doi:10.1007/s10508-010-9691-3

Owens, R. E. (1998). Queer kids: The challenges and promise for lesbian, gay, and bisexual youth. Binghamton, NY: Haworth Press.

Padula v. Webster, 822 F.2d 97 (D.C. Cir 1987).

Parks, C. A., Hughes, T. L., \& Matthews, A. K. (2004). Race/ethnicity and sexual orientation: Intersecting identities. Cultural Diversity and Ethnic Minority Psychology, 10(3), 241-254.

doi:10.1037/1099-9809.10.3.241

Perry v. Schwarzenegger, 704 F.Supp.2d 921 (N.D. Cal. 2010).

Plummer, K. (2005). Critical humanism and queer theory: Living with the tensions. In N. K. Denzin \& Y. S. Lincoln (Eds.), The Sage handbook of qualitative research (3rd ed., pp. 357-373). Thousand Oaks, CA: Sage.

Plummer, K. (2007). Queers, bodies, and postmodern sexualities: A note on revisiting the "sexual" in symbolic interactionism. In M. Kimmel (Ed.), The sexual self: The construction of sexual scripts (pp. 16-30). Nashville, TN: Vanderbilt University Press. Ponse, B. (1978). Identities in the lesbian world: The social construction of self. Westport, CT: Greenwood Press.

Priebe, G., \& Svedin, C. G. (2013). Operationalization of three dimensions of sexual orientation in a national survey of late adolescents. Journal of Sex Research, 50(8), 727-738.

doi:10.1080/00224499.2012.713147

Queen, C. (1999). Strangers at home: Bisexuals in the queer movement. In L. P. Gross \& J. D. Woods (Eds.), The Columbia reader on lesbians and gay men in media, society, and politics (pp. 105-108). New York, NY: Columbia University Press.

Rahman, Q. (2005). The neurodevelopment of human sexual orientation. Neuroscience and Biobehavioral Reviews, 29(7), 1057-1066. doi:10.1016/j.neubiorev.2005.03.002

Rahman, Q. (2015, July 24). "Gay genes": Science is on the right track, we're born this way. Let's deal with it. The Guardian. Retrieved from

http:/ /www.theguardian.com/science/blog/2015/jul/24/gay-genesscience-

is-on-the-right-track-were-born-this-way-lets-deal-with-it 


\section{THE JOURNAL OF SEX RESEARCH, 53(4-5), 363-391 (2016)}

Reinisch, J. M., \& Sanders, S. A. (1992). Prenatal hormonal contributions to sex differences in human cognitive and personality development. In A. A. Gerall, H. Moltz, \& I. L. Ward (Eds.), Sexual differentiation (pp. 221-243). New York, NY: Plenum Press.

Respondent's Brief, Lawrence v. Texas, 539 U.S. 558 (2003).

Reyna, C., Wetherell, G., Yantis, C., \& Brandt, M. J. (2014). Attributions for sexual orientation vs. stereotypes: How beliefs about value violations account for attribution effects on anti-gay discrimination. Journal of Applied Social Psychology, 44(4), 289-302. doi:10.1111/jasp.12226

Rice, W. R., Friberg, U., \& Gavrilets, S. (2012). Homosexuality as a consequence of epigenetically canalized sexual development. Quarterly Review of Biology, 87(4), 343-368. doi:10.1086/668167

Rich, A. (1980). Compulsory heterosexuality and lesbian existence. Signs: Journal of Women in Culture and Society, 5, 631-660. doi:10.1086/493756

Richardson, S. S., \& Stevens, H. (Eds.). (2015). Postgenomics. Durham, NC: Duke University Press.

Rieger, G., Bailey, J. M., \& Chivers, M. L. (2005). Sexual arousal patterns of bisexual men. Psychological Science, 16, 579-584. doi:10.1111/j.1467-9280.2005.01578.x

Rieger, G., \& Savin-Williams, R. C. (2012). The eyes have it: Sex and sexual orientation differences in pupil dilation patterns. PLoS ONE, 7, 8. doi:10.1371/journal.pone.0040256

Rimer, S. (1993, June 5). Campus lesbians step into unfamiliar light. New York Times, p. A2.

Romer v. Evans, 517 U.S. 620 (1996).

Rosario, M., \& Schrimshaw, E. W. (2014). Theories and etiologies of sexual orientation. In D. L. Tolman \& L. M. Diamond (Eds.), APA handbook of sexuality and psychology, Vol. 1: Person-based approaches (pp. 555-596). Washington, DC: American Psychological Association.

Rosario, M., Schrimshaw, E. W., \& Hunter, J. (2004). Ethnic/racial differences in the coming-out process of lesbian, gay, and bisexual youths: A comparison of sexual identity development over time. Cultural Diversity and Ethnic Minority Psychology, 10(3), 215-228. doi:10.1037/1099-9809.10.3.215

Rosario, V. A. (2002). Homosexuality and science: A guide to the debates. Santa Barbara, CA: ABCCLIO.

Roselli, C. E., \& Stormshak, F. (2009). Prenatal programming of sexual partner preference: The ram model. Journal of Neuroendocrinology, 21(4), 359-364. doi:10.1111/jne.2009.21.issue-4

Rosenthal, A. M., Sylva, D., Safron, A., \& Bailey, J. M. (2011). Sexual arousal patterns of bisexual men revisited. Biological Psychology, 88 (1), 112-115. doi:10.1016/j.biopsycho.2011.06.015 


\section{THE JOURNAL OF SEX RESEARCH, 53(4-5), 363-391 (2016)}

Rosenthal, A. M., Sylva, D., Safron, A., \& Bailey, J. M. (2012). The male bisexuality debate revisited: Some bisexual men have bisexual arousal patterns. Archives of Sexual Behavior, 41, 135-147. doi:10.1007/s10508-011-9881-7

Rosky, C. J. (2013a). Fear of the queer child. Buffalo Law Review, 61(3), 607-697.

Rosky, C. J. (2013b). No promo hetero. Cardozo Law Review, 35, 425-510.

Ross, M. W., Daneback, K., \& Månsson, S.-A. (2012). Fluid versus fixed: A new perspective on bisexuality as a fluid sexual orientation beyond gender. Journal of Bisexuality, 12(4), 449-460. doi:10.1080/15299716.2012.702609

Rowland v. Mad River Local School District, 470 U.S. 1009 (1985).

Rupp, H. A., \& Wallen, K. (2007). Sex differences in viewing sexual stimuli: An eye-tracking study in men and women. Hormones and Behavior, 51(4), 524-533. doi:10.1016/j.yhbeh.2007.01.008

Russell, S. T., Clarke, T. J., \& Clary, J. (2009). Are teens “post-gay”? Contemporary adolescents' sexual identity labels. Journal of Youth and Adolescence, 38(7), 884-890. doi:10.1007/s10964-0089388-2

Rust, P. C. R. (1993). Neutralizing the political threat of the marginal woman: Lesbians' beliefs about bisexual women. Journal of Sex Research, 30(3), 214-228. doi:10.1080/00224499309551705

Rust, P. C. R. (2000a). Academic literature on situational homosexuality in the 1960s and 1970s. In P. C. R. Rust (Ed.), Bisexuality in the United States: A reader and guide to the literature (pp. 221249). New York, NY: Columbia University Press.

Rust, P. C. R. (2000b). Alternatives to binary sexuality: Modeling bisexuality. In P. C. R. Rust (Ed.), Bisexuality in the United States (pp. 33-54). New York, NY: Columbia University Press.

Rust, P. C. R. (2000c). Criticisms of the scholarly literature on sexuality for its neglect of bisexuality. In P. C. R. Rust (Ed.), Bisexuality in the United States: A reader and guide to the literature (pp. 510). New York, NY: Columbia University Press.

Rust, P. C. R. (2009). Bisexuality in a house of mirrors: Multiple reflections, multiple identities. In P. L. Hammack \& B. J. Cohler (Eds.), The story of sexual identity: Narrative perspectives on the gay and lesbian life course (pp. 107-129). New York, NY: Oxford University Press.

Sandel, M. (1989). Moral argument and liberation toleration: Abortion and homosexuality. California Law Review, 77, 521-538.

Savin-Williams, R. C. (2005). The new gay teenager. Cambridge, MA: Harvard University Press.

Savin-Williams, R. C. (2006). Who's gay? Does it matter? Current Directions in Psychological Science, 15(1), 40-44. doi:10.1111/cdir.2006.15.issue-1 


\section{THE JOURNAL OF SEX RESEARCH, 53(4-5), 363-391 (2016)}

Savin-Williams, R. C., \& Joyner, K. (2014). The dubious assessment of gay, lesbian, and bisexual adolescents of Add Health. Archives of Sexual Behavior, 43(3), 413-422. doi:10.1007/s10508-0130219-5

Savin-Williams, R. C., Joyner, K., \& Rieger, G. (2012). Prevalence and stability of self-reported sexual orientation identity during young adulthood. Archives of Sexual Behavior, 41, 103-110. doi:10.1007/s10508-012-9913-y

Savin-Williams, R. C., \& Ream, G. L. (2007). Prevalence and stability of sexual orientation components during adolescence and young adulthood. Archives of Sexual Behavior, 36(3), 385-394. doi:10.1007/s10508-006-9088-5

Savin-Williams, R. C., Rieger, G., \& Rosenthal, A. M. (2013). Physiological evidence for a mostly heterosexual orientation among men [Letter to the editor]. Archives of Sexual Behavior, 42, 697699. doi:10.1007/s10508-013-0093-1

Savin-Williams, R. C., \& Vrangalova, Z. (2013). Mostly heterosexual as a distinct sexual orientation group: A systematic review of the empirical evidence. Developmental Review, 33(1), 58-88. doi:10.1016/j.dr.2013.01.001

Schmeiser, S. R. (2009). Changing the immutable. Connecticut Law Review, 41(5), 1495-1522.

Sedgwick, E. (1990). The epistemology of the closet. Berkeley: University of California Press.

Seto, M. C., Abramowitz, C. S., \& Barbaree, H. E. (2008). Paraphilias. In J. Hunsley \& E. J. Mash (Eds.), A guide to assessments that work (pp. 488-512). New York, NY: Oxford University Press.

Singer v. Hara, 522 P.2d 1187 (Wash. 1974).

Smith, W. (2014, February 13). Beware sexual orientation eugenic cleansing.

National Review. Retrieved from http://www.nationalreview.com/humanexceptionalism/371101/beware-sexual-orientation-eugeniccleansing-wesley-j-smith

Starks, T. J., Nadler, J. T., Sagrestano, L. M., \& Sarvela, P. D. (2009).

Examining discrepancies among sexual orientation components in a representative sample of men at risk for HIV/AIDS. Journal of Gay and Lesbian Mental Health, 13(4), 234-252.

doi:10.1080/19359700903012039

Stein, E. (2014). Immutability and innateness arguments about lesbian, gay, and bisexual rights. Chicago-Kent Law Review, 89, 597-640.

Sullivan, A. (1995). Virtually normal. New York, NY: Knopf.

Suschinsky, K. D., Lalumiere, M. L., \& Chivers, M. L. (2009). Sex differences in patterns of genital sexual arousal: Measurement artifacts or true phenomena? Archives of Sexual Behavior, 38(4), 559573. doi:10.1007/s10508-008-9339-8 


\section{THE JOURNAL OF SEX RESEARCH, 53(4-5), 363-391 (2016)}

Sweet, T., \& Welles, S. L. (2012). Associations of sexual identity or same-sex behaviors with history of childhood sexual abuse and HIV/STI risk in the United States. Journal of Acquired Immune Deficiency Syndromes, 59(4), 400-408. doi:10.1097/QAI.0b013e3182400e75

TallBear, K. (2007). Narratives of race and indigeneity in the genographic project. Journal of Law, Medicine, and Ethics, 35(3), 412-424. doi:10.1111/j.1748-720X.2007.00164.x

TallBear, K. (2008). Native-American-DNA.com: In search of Native American race and tribe. In B. A. Koenig, S. S.-J. Lee, S. S.

Richardson, B. A. Koenig, S. S.-J. Lee, \& S. S. Richardson (Eds.), Revisiting race in a genomic age (pp. 235-252). Piscataway, NJ: Rutgers University Press.

TallBear, K. (2013). Native American DNA: Tribal belonging and the false promise of genetic science. Minneapolis: University of Minnesota Press.

Throckmorten, W. (2008, November 12). Lisa Diamond: NARTH distorts my research. Patheos. Retrieved from http://www.patheos.com/blogs/warrenthrockmorton/2008/11/12/lisa-diamondnarth-distorts-myresearch/

Throckmorten, W. (2009, August 31). Michael Bailey reacts to "blatant misquotation" on LDS website by Byrd, Cox, and Robinson. Patheos. Retrieved from http://www.patheos.com/blogs/warrenthrockmorton/2009/08/31/michael-bailey-reacts-toblatant-misquotation-on-lds-website-by-byrd-cox-and-robinson/

Throckmorten, W. (2013). Over 200 scientists and mental health professionals respond to President Museveni regarding Uganda's anti-gay bill. Patheos. Retrieved from http:/ /www.patheos.com/blogs/warrenthrockmorton/2014/02/13/over-200-scientists-andmental-health-professionals-respond-to-president-museveni-regarding-ugandas-anti-gaybill/

Transcript of Oral Argument in Obergefell v. Hodges, No. 14556 (2015).

Transcript of Oral Argument in Perry v. Hollingsworth, No. 12-144 (2013).

Tweedy, A. E. (2011). Polygamy as sexual orientation. University of Cincinnati Law Review, 79, 1461-1515.

United States v. Carolene Products Co., 304 U.S. 144 (1938).

United States v. Windsor, 133 S.Ct. 2675 (2013).

Valdes, F. (1997). Queer margins, queer ethics: A call to account for race and ethnicity in the law, theory, and politics of sexual orientation. Hastings Law Review, 48, 1293-1342.

Vargas, H., \& O’Donnell, N. M. (2013). Brief of amicus curiae GLMA: Health professionals advancing LGBT equality (Gay and Lesbian Medical Association) concerning the immutability of sexual orientations in support of affirmance on the merits, Windsor, 133 S. Ct. 2675 (Nos. 12-307). 


\section{THE JOURNAL OF SEX RESEARCH, 53(4-5), 363-391 (2016)}

Varnum v. Brien, 763 N.W.2d 862 (Iowa 2009).

Vasey, P. L. (2002). Same-sex sexual partner preference in hormonally and neurologically unmanipulated animals. Annual Review of Sex Research, 13, 141-179.

Warner, M. (1999). The trouble with normal: Sex, politics, and the ethics of queer life. New York, NY: Free Press.

Warren, P. N. (2009, January 4). Civil rights for gays: Does “immutable" really describe us? Huffington Post. Retrieved from http://www.huffingtonpost.com/patricia-nell-warren/civil-rightsfor-gays-doe_b_148587.html

Watkins v. U.S. Army, 847 F.2d 1329 (9nd Cir. 1989).

Weber v. Aetna Casualty \& Surety Co., 406 U.S. 164 (1972).

Wells, J. E., McGee, M. A., \& Beautrais, A. L. (2011). Multiple aspects of sexual orientation: Prevalence and sociodemographic correlates in a New Zealand national survey. Archives of Sexual Behavior, 40(1), 155-168. doi:10.1007/s10508-010-9636-x

Welzer-Lang, D., \& Tomolillo, S. (2008). Speaking out loud about bisexuality: Biphobia in the gay and lesbian community. Journal of Bisexuality, 8(1-2), 81-95. doi:10.1080/15299710802142259

Whisman, V. (1993). Identity crisis: Who is a lesbian anyway? In I. A. Stein (Ed.), Sisters, sexperts, queers: Beyond the lesbian nation (pp. 47-60). New York, NY: Penguin.

Whisman, V. (1996). Queer by choice: Lesbians, gay men, and the politics of identity. New York, NY: Routledge.

Whitewood v. Wolf, 992 F.Supp.2d 410 (W.D. Penn 2014).

Windsor v. United States, 699 F.3d 169 (2nd Cir. 2012).

Witchel, L. (2012, January 19). Life after "sex.” New York Times Magazine. Retrieved from http:/ /www.nytimes.com/2012/01/22/magazine/cynthia-nixon-wit.html

Wolf v. Walker, 986 F.Supp.2d 982 (W.D. Wisc 2014).

Yoshino, K. (1998). The assimilationist bias in equal protection. Yale Law Journal, 108, 494-571.

Yoshino, K. (2000). The epistemic contract of bisexual erasure. Stanford Law Review, 52(2), 353. doi:10.2307/1229482

Yost, M. R., \& McCarthy, L. (2012). Girls gone wild? Heterosexual women's same-sex encounters at college parties. Psychology of Women Quarterly, 36(1), 7-24. doi:10.1177/0361684311414818 
THE JOURNAL OF SEX RESEARCH, 53(4-5), 363-391 (2016)

Yost, M. R., \& Thomas, G. D. (2012). Gender and binegativity: Men's and women's attitudes toward male and female bisexuals. Archives of Sexual Behavior, 41(3), 691-702. doi:10.1007/s10508-0119767-8 